\title{
Buying Promises: How Citizens United's Campaign Expenditures Convert Our "Impartial” Judges and Their Nonpromissory Campaign Statements into an Indebted, Influenced, and Dependent Judiciary ${ }^{*}$
}

\section{INTRODUCTION}

[W] cannot have even a baseball game without an impartial umpire to enforce the rules of the game and settle controversies that may arise between the players; and there can be no such thing as a peaceful society in the absence of an impartial judiciary to settle controversies on the basis of what is just and right and to direct the power of the state in the enforcement of law.

Imagine this scenario: You play for the Atlanta Braves, who are in the final game of the World Series against the Yankees. The ballgame is tied in the top of the ninth with two outs, and when you step up to bat, you hit the ball into the stands right by the foul pole. However, it is unclear to you whether the ball flew behind or in front of the pole. The game, the championship, and possibly your career are riding on the home plate umpire's call. He calls it a foul. The Yankees go on to win. Naturally, you would feel a great sense of disappointment but, nevertheless, know that the Yankees won it fair and square.

Now, imagine that umpires were elected to their jobs and that during his "umpire campaign," the home plate umpire made a campaign statement that he believed the American League was better than the National League. As a result of this statement, a particular corporation

Jill E. Moenius. J.D. candidate 2012, University of Kansas School of Law; B.S. 2009, University of Arkansas. I would like to thank Professors William Westerbeke and Stephen McAllister for their initial guidance on this issue and Professor Richard Levy for his helpful feedback throughout the writing process. I would also like to thank Melissa Plunkett, Milos Jekic, Jacob Gontesky, Alex Aguilera, and the rest of the Kansas Law Review board and staff for their hard work during the editing process. Lastly, I would like to thank my family: just as independence is the sine qua non of judicial success, their continuous love and support is the sine qua non of my accomplishments.

1. John J. Parker, The Judicial Office in the United States, 23 N.Y.U. L. Q. REV. 225, 225 (1948). 
affiliated with the American League expended substantial sums of money on advertisements supporting the umpire candidate. Now elected, he is umpiring the biggest game in baseball and feels a deep sense of gratitude towards the organization that supported him.

The truth is, when your ball flew past the foul pole, the home plate umpire really had no clue which side of the pole it passed. However, he felt pressured, indebted, and dependent on the corporation that essentially got him his job. So instead of conferencing with the other umpires and carefully considering what should be done, he recklessly called the play in favor of the Yankees. Now do you feel like the Yankees won it fair and square? Of course not.

As shocking as the above scenario seems, it is an accurate reflection of what has become of our elected judiciary. Similar to an umpire's duty to impartially call plays, the role of a judge is to impartially carry out the administration of justice. ${ }^{2}$ But this paramount duty has been lost in the politics that have so fiercely taken over our elected judiciary. What began in the Jackson era-when the first judicial elections were held-as an attempt to ensure that judges were not agents of the legislature has snowballed into an unjust reality of our judges acting partially as agents of the electorate. ${ }^{3}$ This Comment asserts that judicial candidates' ability to announce their views on disputed legal issues, coupled with unrestricted corporate spending in judicial elections, has completely destroyed the independence of our elected judiciary by allowing "special interests” to buy promises of partial decisions from a particular candidate if elected.

Part II of this Comment will begin by exploring the evolution of judicial elections and their regulation. Since 1924, opponents of judicial elections have been trying to minimize the risks that come with such elections through campaign regulations in codes of judicial conduct. ${ }^{4}$ Among these regulations are provisions known as announce, commit, and pledges or promises clauses that restrict what judicial candidates can say during campaigns. ${ }^{5}$ Because judges must carry out their duties impartially, these campaign speech regulations aim to prevent judges from binding themselves to a particular disposition with regard to a

2. Id.

3. See infra Part II.A.

4. Matthew J. Streb \& Brian Frederick, Judicial Reform and the Future of Judicial Elections, in RunNing for Judge: The Rising Political, Financial, and Legal Stakes of Judicial ELECTIONS 204, 205-06 (Matthew J. Streb ed., 2007).

5. See infra Part II.B. 
particular issue-in case the issue comes before them in the future if elected. ${ }^{6}$

Next, Part II will explore the deterioration of these judicial campaign speech regulations. In 2002, in Republican Party of Minnesota v. White, the Supreme Court struck down Minnesota's announce clause as unconstitutional under the First Amendment. ${ }^{7}$ White's holding sparked a trend among states that ultimately led some states to eliminate judicial campaign speech regulations altogether. ${ }^{8}$ This Comment will explore the Court's holding and reasoning in White and then discuss how courts have struggled with White's application to other campaign regulations such as the pledges or promises and commit clauses.

Part II will conclude by discussing issues involved with campaign expenditures. Specifically, this Comment will focus on the Court's holding in Caperton v. A.T. Massey Coal Co., ${ }^{9}$ requiring judges to recuse themselves when substantial funds were used by a litigant to place the judge on the bench, as well as the Court's decision in Citizens United $v$. FEC. ${ }^{10}$ In Citizens United, the Supreme Court put the final nail in the coffin of an independent elected judiciary when it held that the First Amendment prohibited restrictions on corporate campaign expenditures. ${ }^{11}$ Permitting corporations to expend unrestricted sums from their treasury funds to ensure that a particular candidate is put on the bench, combined with the substantial deterioration of our judicial campaign speech regulations, eliminates what little independence remained in the elected judiciary.

Part III of this Comment will begin by analyzing how elections have caused the judiciary to become partial. Next, it will focus on the scope and constitutionality of additional judicial campaign speech regulations under the White framework. Then, after hesitantly accepting the Court's conclusion in White, Part III will establish that Citizens United and White cannot live together because substantial Citizens United campaign expenditures convert White's nonpromissory campaign statements into implied promises between the candidate and the expending organization. Next, Part III will propose that the only way to maintain any impartiality for judges in states that utilize judicial elections is by either overturning White or narrowing the application of Citizens United by excluding

6. See infra Part II.B.

7. 536 U.S. 765,765 .

8. See infra Part II.B.

9. 129 S. Ct. 2252 (2009).

10. 130 S. Ct. 876 (2010).

11. Id. at 913 . 
judicial elections from its holding. Finally, this Comment will conclude by suggesting that until the severance of White and Citizens United is accomplished —if ever—states should protect the impartiality of their judiciaries by increasing their recusal standards.

\section{BACKGROUND}

\section{A. The Evolution of Judicial Selection}

The politics inherent in the electoral process have steadily contaminated the independence of our elected judiciary. There once was a time, however, when our impartial judges were not transformed into politicians. States have not always elected their judges. ${ }^{12}$ Until the Jackson era, state judges were appointed. ${ }^{13}$ In some states, the legislature made the selections, and in other states, the governor made the selections. ${ }^{14}$ Then, in the mid-nineteenth century, the rise of Jacksonian democracy coincided with a shift to and rise of judicial elections. ${ }^{15}$ By the Civil War, a majority of states elected their judges. ${ }^{16}$

The emergence of state judicial elections was primarily attributed to the desire for an independent judiciary. ${ }^{17}$ "[T] $[$ he legal profession ... believed that, as an independent branch of government, the judiciary should not be an agent of the legislature" 18 and would gain a degree of independence if provided with its own separate constituency. ${ }^{19}$ However, almost as quickly as state judicial elections gained popularity, they also garnered criticism. ${ }^{20}$

State judicial elections started off as partisan and, therefore, very much controlled by politics, which led to corruption. ${ }^{21}$ In 1906, Roscoe Pound, Dean of Harvard Law School at the time, spoke before the

12. See Polly J. Price, Selection of State Court Judges, in STATE JudiCiARIES AND IMPARTiality: JUdGing THE JUdGES 9, 12-13 (Roger Clegg \& James D. Miller eds., 1996).

13. See id.

14. Chris W. Bonneau \& Melinda Gann Hall, in Defense of Judicial Elections 4 (2009).

15. Id. at 5; Price, supra note 12, at 13.

16. Larry C. Berkson, Judicial Selection in the United States: A Special Report, 64 JUDICATURE 176, 176 (1980).

17. BONNEAU \& HALL, supra note 14 , at 7 .

18. Id. at 5,7 .

19. Id. at 5.

20. Price, supra note 12, at 14 .

21. Matthew J. Streb, The Study of Judicial Elections, in RUNNING FOR JUDGE, supra note 4, at 1, 9-10. 
American Bar Association (ABA), disapproving of judicial elections. ${ }^{22}$ An excerpt from Pound's speech is often quoted to describe the views of those who advocated for the judicial appointment system's return: "Putting courts into politics and compelling judges to become politicians... has almost destroyed the traditional respect for the bench."23

The dissatisfaction with partisan judicial elections sparked further judicial selection reform. ${ }^{24}$ The first reform was the emergence of nonpartisan judicial elections. ${ }^{25}$ Proponents of nonpartisan elections believed "partisanship had little to do with judging" 26 and hoped the removal of candidates' party affiliation from the ballot would eliminate the corruptness that had become entangled in judicial elections. ${ }^{27}$ The removal of party affiliation from the ballot, however, did not completely remove politics from judicial elections - the most obvious reason being that judicial candidates still had to campaign for office. ${ }^{28}$ Moreover, the removal of party affiliation resulted in lower voter turnout in judicial elections. ${ }^{29}$ Some worried the decrease in voting would cause close races to be determined by "special interests such as insurance companies, big business, labor unions or segments of the legal profession." Dissatisfaction with nonpartisan judicial elections grew almost as fast as it did with partisan elections. ${ }^{31}$

Those still dissatisfied with judicial elections turned to further reform known as the "merit plan," endorsed by the ABA in $1937 .{ }^{32}$ The merit plan—also known today as the "Missouri Plan"33_involves the governor initially appointing judges from a list of candidates put forth by a

\footnotetext{
22. Price, supra note 12 , at 14 .
}

23. Roscoe Pound, The Causes of Popular Dissatisfaction with the Administration of Justice, 14 AM. LAW. 445, 450 (1906); see CHARLES H. SHELdON \& LindA S. MAUle, ChOOSING JustiCE: THE RECRUITMENT of StATE AND FEDERAL Judges 5 (1997); Berkson, supra note 16, at 177; Price, supra note 12, at 14; Streb, supra note 21 , at 10.

24. Streb, supra note 21 , at 10 .

25. Id.

26. SHELDON \& MAULE, supra note 23, at 5.

27. Streb, supra note 21 , at 10.

28. Id.

29. SHELDON \& MAULE, supra note 23, at 6.

30. Id.

31. See Berkson, supra note 16, at 177 (stating that criticism of nonpartisan elections started almost as soon as the elections began).

32. Philip L. Dubois, From Ballot to BenCH: Judicial Elections AND The Quest FOR ACCOUNTABILITY 4 (1980).

33. Streb, supra note 21 , at 11 . 
nominating commission. ${ }^{34}$ Then, in periodic retention elections, the public votes on whether the judges appointed by the governor should be retained in office. ${ }^{35}$ Nationwide approval of the merit plan quickly grew, and it "is the most common judicial selection method today."36

Nevertheless, judicial elections have not disappeared and are still very much a part of several states' judicial selection process. ${ }^{37}$ And with state judicial elections still in existence, so are their critics. ${ }^{38}$ In fact, the ABA opposes judicial elections, stating in a 2003 report: "If we were writing on a clean slate, based on what we now see in how judicial campaigns have come to be conducted...judicial elections would gradually be abandoned." ${ }^{39}$ Judicial elections are criticized and condemned on several levels, including their damaging effect on the judiciary's impartiality and independence. ${ }^{40}$ Yet because many states still select their judges through judicial elections, opponents of judicial elections have turned to campaign regulation as a means of minimizing the negative impact elections have on the judiciary. ${ }^{41}$

\section{B. Regulation of Judicial Elections}

When a judicial candidate announces his or her view on a particular legal issue, the impartiality of our judiciary is threatened because the candidate is suggesting how he or she would decide that issue if elected. If a "special interest" then heavily invests in the candidate on the basis of

34. PAtrick M. McFAdden, Electing Justice: The LAW AND ETHics OF Judicial EleCtion CAMPAIGNS 5 (1990). A nominating commission is composed of lawyers, laypersons, and judges who evaluate judicial candidates before nominating. SHELDON \& MAULE, supra note 23, at 7.

35. MCFADDEN, supra note 34, at 5 .

36. Streb, supra note 21, at 11 . However, it should be noted that there are still critics of the merit plan.

Opponents of a merit selection system argue: (1) merit selection is undemocratic; (2) judges are selected by small elite groups; (3) merit selection allows for removal, but not selection; (4) politics is still a factor at the nomination and appointment level; (5) it is a secretive process; (6) bar polls do not accurately reflect the interest of citizens; and (7) contested elections make judges accountable and responsive.

Jay A. Daugherty, The Missouri Non-partisan Court Plan: A Dinosaur on the Edge of Extinction or a Survivor in a Changing Socio-Legal Environment?, 62 Mo. L. REV. 315, 319 (1997).

37. Ruth Ann Watry, The People Who Serve in State Court Systems, in THE JUDICIAL BRANCH of State Government: People, Process, And Politics 139, 142-43 (Sean O. Hogan ed., 2006).

38. DuBOIS, supra note 32, at 5.

39. AM. BAR ASS'N COMM'N ON THE 21ST CENTURY JUDICIARY, JUSTICE IN JEOPARDY, at Xii (2003), available at http://www.americanbar.org/content/dam/aba/migrated/judind/jeopardy/pdf/ report.authcheckdam.pdf.

40. DuBOIS, supra note 32, at 5-6.

41. Streb \& Frederick, supra note 4, at 206-07. 
his or her announcement, the announcement converts into an implied promise-inconsistent with the impartiality of our judiciary-about how the particular issue will be decided if the candidate is elected. Judicial candidates, however, have not always been able to seek support by announcing their views on disputed legal issues.

States have restricted judicial campaign conduct since $1924 .{ }^{42}$ One regulation that consistently had been a part of these restrictions was known as the "announce" clause, which put limitations on the statements judicial candidates could make about their views on disputed legal issues. $^{43}$ The Model Canons of Judicial Ethics, approved by the ABA in 1924, contained an announce clause stating that a judicial candidate "should not announce in advance his conclusions of law on disputed issues to secure class support." ${ }^{44}$ The 1924 Canons, however, were not widely accepted, and by the mid-twentieth century, only eleven states had adopted the Canons. ${ }^{45}$ The 1924 Canons were not written with the intention of being "“a basis for disciplinary action"”,46 and were criticized for being "more hortatory than helpful in providing firm guidance for the solution of difficult questions." 47

Then, in 1972, the ABA adopted the Model Code of Judicial Conduct. ${ }^{48}$ The Code resolved the problems involved with the Canons by establishing clearer, mandatory standards. ${ }^{49}$ The Code broadened the scope of the announce clause by prohibiting judicial candidates from announcing their views on "disputed legal issues," regardless of whether the statement's purpose was to "secure class support."50

Many viewed the newer and broader announce clause as an excessive limitation on speech and, therefore, a violation of the First

42. MCFADDEN, supra note 34, at 86.

43. See Jim Walker, The Politics of State Courts, in ThE Judicial BRANCH OF STATE GOVERNMENT, supra note 37, at 171, 180.

44. CANONS OF JUDICIAL ETHICS Canon 30 (1924).

45. See Republican Party of Minn. v. White, 536 U.S. 765, 786 (2002) (quoting J. MACKENZIE, THE APPEARANCE OF JUSTICE 191 (1974)).

46. Richard Briffault, Judicial Campaign Codes After Republican Party of Minnesota v. White, 153 U. PA. L. REV. 181, 202 (2004) (quoting Rick A. Johnson, Judicial Campaign Speech in Kentucky After Republican Party of Minnesota v. White, 30 N. KY. L. REV. 347, 353 (2003)).

47. Robert B. McKay, Judges, the Code of Judicial Conduct, and Nonjudicial Activities, 1972 UTAH L. REV. 391, 391.

48. Id.

49. Id.

50. See Model Code of Judicial Conduct Canon 7(B)(1)(c) (1972) (amended 2007); see also MCFADDEN, supra note 34, at 86 ("The Model Code of Judicial Conduct... significantly narrowed the range of permissible political talk. . . . Any matter of contemporary political interest, so long as it is controversial, is ruled out of bounds.”). 
Amendment rights of judicial candidates. ${ }^{51}$ In fact, several courts struck the clause down as unconstitutional. ${ }^{52}$ Therefore, in 1990, the ABA eliminated the announce clause from the Code to make the Code less restrictive on judicial candidate speech. ${ }^{53}$ The provision that replaced the 1972 announce clause, which is referred to as the "commit" clause, ${ }^{54}$ stated that judicial candidates could not "make statements that commit or appear to commit the candidate...to ... issues... likely to come before the court."55 This new restriction aimed to strike a balance between the First Amendment rights of judicial candidates and the impartiality of the judiciary. ${ }^{56}$ But despite the ABA erasing the announce clause from the Code, nine states still kept the 1972 announce clause in their judicial codes until 2002, when the Supreme Court of the United States decided Republican Party of Minnesota $v$. White. ${ }^{57}$

\section{Republican Party of Minnesota v. White}

Minnesota's Constitution has provided for judicial elections ever since Minnesota entered the Union in 1858, and the elections have been nonpartisan since $1912 .^{58}$ In 1974, Minnesota incorporated the announce clause into its judicial code. ${ }^{59}$ Minnesota's announce clause was based entirely on the ABA's 1972 Code and stated that a judicial candidate could not "'announce his or her views on disputed legal or political issues.”,60

In 1996, Gregory Wersal, a judicial candidate for associate justice of the Minnesota Supreme Court, circulated literature while campaigning that criticized numerous Minnesota Supreme Court decisions. ${ }^{61}$

51. Neil K. Sethi, The Elusive Middle Ground: A Proposed Constitutional Speech Restriction for Judicial Selection, 145 U. PA. L. REV. 711, 737-38 (1997).

52. See id. at 740-45.

53. See Walker, supra note 43 , at 180 .

54. Richard L. Hasen, First Amendment Limits on Regulating Judicial Campaigns, in RUNNING FOR JUDGE, supra note 4, at 15, 17.

55. Model Code Of Judicial Conduct Canon 5(A)(3)(d)(ii) (1990) (amended 2007).

56. See Walker, supra note 43, at 180.

57. See Katherine A. Moerke, Must More Speech Be the Solution to Harmful Speech? Judicial Elections After Republican Party of Minnesota v. White, 48 S.D. L. REV. 262, 267-68 (2003).

58. Republican Party of Minn. v. White, 536 U.S. 765, 768 (2002); see also Price, supra note 12 , at 13 (stating that every state to enter the union between 1845 and 1912 provided for judicial elections).

59. White, 536 U.S. at 768.

60. Id. (quoting Minn. Code of Judicial Conduct Canon 5(A)(3)(d)(i) (2000) (abrogated 2009)).

61. Id. 
Subsequently, an ethics complaint was filed against Wersal, which included charges that the literature he distributed violated Minnesota's announce clause. $^{62}$ The complaint was eventually dropped; however, wary of the potential adverse effects of future ethics complaints, Wersal withdrew from the judicial election. ${ }^{63}$

Two years later, Wersal entered the election for the same office, but early into the campaign, he filed suit in federal district court against officers of the Minnesota Board on Judicial Standards and the Minnesota Lawyers Professional Responsibility Board, seeking "a declaration that the announce clause violate[d] the First Amendment and an injunction against its enforcement." ${ }^{\text {"4 }}$ The district court held that the announce clause did not violate the First Amendment because it served "the state's compelling interest in maintaining the ... integrity and independence of its judiciary, while not unnecessarily curtailing protected speech.”65 Wersal appealed the case to the United States Court of Appeals for the Eighth Circuit, which affirmed the district court's holding. ${ }^{66}$ In 2001, the United States Supreme Court granted certiorari. ${ }^{67}$ In a five-to-four decision, the Supreme Court found that Minnesota's announce clause violated the First Amendment and, thus, reversed the Eighth Circuit's ruling. ${ }^{68}$

\section{a. The Supreme Court's Definition of the Announce Clause}

In White, Justice Scalia wrote for the majority and began his opinion by ascertaining the meaning of Minnesota's announce clause. ${ }^{69}$ To define the announce clause, the Court distinguished an announcement from a promise: "We know that 'announc[ing] ... views' on an issue covers much more than promising to decide an issue a particular way. The prohibition extends to the candidate's mere statement of his current position, even if he does not bind himself to maintain that position after election., ${ }^{, 70}$ The Minnesota Code of Judicial Conduct contained a

62. Id. at 768-69.

63. Id. at 769 .

64. Id. at 769-70 \& n.3.

65. Republican Party of Minn. v. Kelly, 63 F. Supp. 2d 967, 986 (D. Minn. 1999), aff'd, 247 F.3d 854 (8th Cir. 2001), rev'd sub nom. White, 536 U.S. 765.

66. Kelly, 247 F.3d at 885.

67. Republican Party of Minn. v. Kelly, 534 U.S. 1054 (2001).

68. White, 536 U.S. at 765.

69. Id. at 770 .

70. Id. (alteration in original) (quoting MinN. CODE OF JUdiCIAL CONDUCT Canon 5(A)(3)(d)(i) (2002) (abrogated 2009)). 
separate clause known as the "pledges or promises" clause, ${ }^{71}$ based on the pledges or promises clause found in the ABA Model Code of Judicial Conduct $^{72}$ and similar to the pledges or promises clauses that most states utilizing judicial elections had adopted. ${ }^{73}$

Next, to more clearly define the scope of Minnesota's announce clause, the Court discussed the limitations that the Minnesota Supreme Court placed on the clause to make it less restrictive. ${ }^{74}$ First, Minnesota's announce clause did not prevent a judicial candidate from criticizing past decisions. ${ }^{75}$ Second, the clause only prohibited statements about "disputed issues that are likely to come before the candidate if he is elected judge."76 Lastly, judicial candidates were still permitted to make general statements about case law and judicial philosophy. ${ }^{77}$

After discussing the limitations that had been placed on the announce clause, Justice Scalia asserted that these limitations did not actually render the clause less restrictive. ${ }^{78}$ First, referring to the limitation that allows criticism of past decisions, Justice Scalia noted that "respondents acknowledged at oral argument that statements critical of past decisions are not permissible if the candidate also states that he is against stare decisis." ${ }^{79}$ In other words, judicial candidates were allowed to be critical of past decisions only as long as they also made it clear that, if elected, they would adhere to stare decisis, regardless of their views on a particular issue. $^{80}$ Next, in discussing the limitation that narrowed the scope of the announce clause to only "disputed issues that are likely to come before the candidate if he is elected," 81 the majority pointed out that the only disputed issues expected to be raised in a state judicial election are those issues that are likely to come before a state court. ${ }^{82}$ Justice Scalia reasoned that it is very unlikely that a state judicial election would spark a discussion about "whether the Federal Government should

\footnotetext{
71. Id.

72. Model Code of Judicial Conduct Canon 5(A)(3)(d)(ii) (1990) (amended 2007).

73. See Hasen, supra note 54, at 17.

74. White, 536 U.S. at 771.

75. Id.

76. Id.

77. Id. at 772 .

78. Id. at $772-73$.

79. Id. at 772 .

80. Id.

81. Id. at 771 .

82. Id. at 772 .
} 
end the embargo of Cuba." ${ }^{83}$ Lastly, the Court contended that the announce clause limitation allowing for discussion of judicial philosophy did not accomplish anything because judicial philosophy means nothing to the electorate unless the philosophy is applied to a specific issue. ${ }^{84}$

After rejecting the limiting effect of each announce clause limitation, Justice Scalia concluded that Minnesota's announce clause could be defined as prohibiting

a judicial candidate from stating his views on any specific nonfanciful legal question within the province of the court for which he is running, except in the context of discussing past decisions - and in the latter context as well, if he expresses the view that he is not bound by stare decisis. ${ }^{85}$

\section{b. The Announce Clause Failed Strict Scrutiny}

Based on the definition of Minnesota's announce clause arrived at by the Court, the majority concluded that the clause prohibited "speech on the basis of its content and burden[ed] a category of speech that is 'at the core of our First Amendment freedoms' - speech about the qualifications of candidates for public office." ${ }^{\prime 6}$ For this reason, the Court needed to analyze the announce clause under the strict scrutiny standard-the clause could be held constitutional only if it served a compelling state interest and was narrowly tailored to serve that interest. ${ }^{87}$ The Court stated that the announce clause would be narrowly tailored only if it did not "'unnecessarily circumscrib[e] protected expression.,"88

The Eighth Circuit determined that the respondents had established two compelling state interests served by the announce clause: preserving impartiality and the appearance of impartiality. ${ }^{89}$ The Supreme Court, however, determined that the respondents were unclear about their definition of impartiality and that a clear definition was needed before it could decide whether impartiality was a compelling state interest. ${ }^{90}$ Therefore, the Court walked through three possible definitions of

\section{Id.}

84. Id. at 773 .

85. Id.

86. Id. at 774 (quoting Republican Party of Minn. v. Kelly, 247 F.3d 854, 861 (8th Cir. 2001), rev'd sub nom. White, 536 U.S. 765).

87. Id. at 774-75.

88. Id. at 775 (quoting Brown v. Hartlage, 456 U.S. 45, 54 (1982)).

89. Id.

90. Id. 
impartiality and determined whether each definition was a compelling state interest and, if so, whether the announce clause was narrowly tailored to serve that interest. ${ }^{91}$

First, the Court analyzed the validity of the announce clause if impartiality were defined as a "lack of bias for or against either party to the proceeding." 92 Although the Court acknowledged that this definition of impartiality was the traditional meaning-and did not refute that it was a compelling interest - the Court concluded that the announce clause was not narrowly tailored to serve this definition of impartiality because it restricted speech about issues, not parties. ${ }^{93}$ Justice Scalia wrote:

[W] hen a case arises that turns on a legal issue on which the judge (as a candidate) had taken a particular stand, the party taking the opposite stand is likely to lose. But not because of any bias against that party, or favoritism toward the other party. ... [Rather, t] the law (as he sees it) evenhandedly.

Next, the Court considered the announce clause's validity if impartiality were defined as the "lack of preconception in favor of or

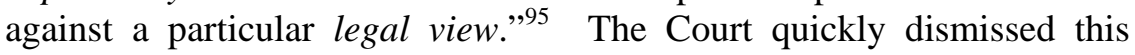
definition, concluding that a lack of preconceptions about the law was not a compelling interest because it is beyond the bounds of possibility to think that a judge without preconceptions about the law exists. ${ }^{96}$

Lastly, the Court discussed the validity of the announce clause if impartiality were defined as "openmindedness."97 The Court explained that an openminded judge would still have preconceptions; however, he would listen to opposing views with an open mind and be willing to be persuaded. $^{98}$ It was proposed that preventing judicial candidates from making statements about their views on disputed legal issues would preserve openmindedness because it would relieve "a judge from pressure to rule a certain way in order to maintain consistency with statements the judge has previously made." ${ }^{99}$ The Court left open the question of whether this definition of impartiality was a compelling state

\footnotetext{
91. Id. at $775-82$.

92. See id. at 775-77.

93. Id. at $776-77$.

94. Id.

95. See id. at 777-78.

96. Id. at 777.

97. See id. at 778-82.

98. Id.

99. Id. at $778-79$.
} 
interest because the Minnesota announce clause at issue did not adopt it. $^{100}$

However, the Court concluded that even if openmindedness was a compelling state interest, the announce clause was not narrowly tailored to serve that interest. ${ }^{101}$ The absence of narrow tailoring, the Court explained, was based on the fact that the announce clause only prohibited speech during judicial campaigns. ${ }^{102}$ The Court reasoned that judicial candidates make statements about disputed legal issues before being a candidate and outside the judicial arena-as guest lecturers, authors, etc. ${ }^{103}$ —and a judge does not necessarily feel more bound to adhere to statements made during a campaign than those made outside of a campaign. ${ }^{104}$

Before reaching the end of its opinion, the majority reiterated the difference between campaign promises and nonpromissory statements, stating that it "might be plausible" that an elected judicial candidate would act without impartiality due to a "reluctance to contradict" campaign promises but that nonpromissory statements are not "uniquely destructive" of impartiality. ${ }^{105}$ The Court ultimately held that Minnesota's announce clause did not pass strict scrutiny and, therefore, "prohibiting candidates for judicial election from announcing their views on disputed . . . issues" violated the First Amendment. ${ }^{106}$

\section{Post-White Regulation of Judicial Candidates' Speech}

The White decision sparked debate about what speech could constitutionally be prohibited during judicial elections. ${ }^{107}$ With the elimination of the announce clause, a few states have completely removed prohibitions of speech about "cases, controversies, or issues that are likely to come before the court" from their judicial codes. ${ }^{108}$ Most states, however, have maintained some level of regulation, and

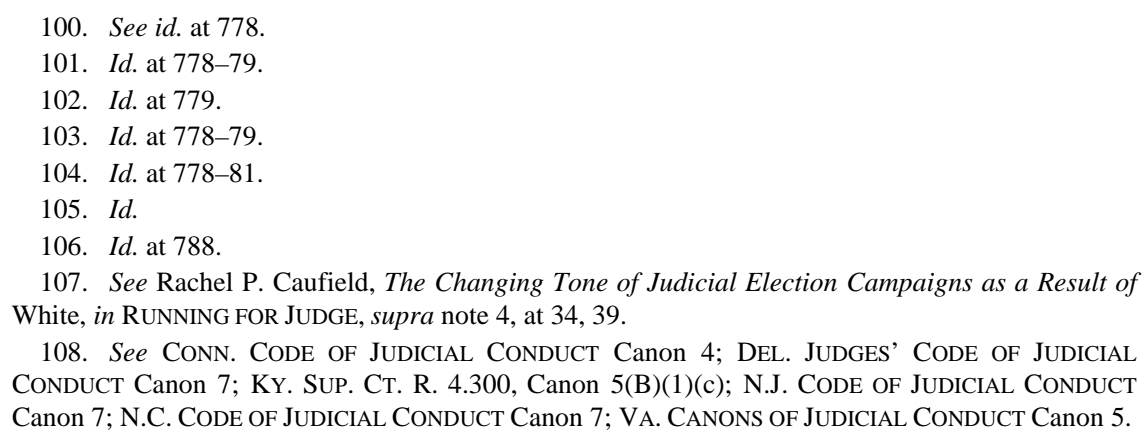


there seem to be two different types of speech regulation that state judicial codes have settled on for "cases, controversies, or issues that are likely to come before the court": the pledges or promises clause and the commit clause. ${ }^{109}$

\section{a. The Pledges or Promises Clause}

A majority of the states that regulate judicial candidate speech have adopted a provision known as the pledges or promises clause. ${ }^{110}$ The pledges or promises clause prohibits judicial candidates from making "pledges or promises of conduct in office other than the faithful and impartial performance of the duties of the office." 111 The basis for the pledges and promises clause is quite clear: if a judicial candidate attempts to gain votes by promises to decide cases in a particular way, his impartiality will be severely handicapped when that particular case comes before him as a judge. ${ }^{112}$

Although a majority of states have adopted a pledges or promises clause, ${ }^{113}$ and despite the fact that the White Court recognized the pledges or promises clause to be narrower than the announce clause, ${ }^{114}$ White has sparked debate over whether the pledges or promises clause is constitutional. ${ }^{115}$ Georgia eliminated the pledges or promises clause from its judicial code after White. ${ }^{116}$ North Carolina, among several other drastic changes to its judicial code, also abolished its pledges or promises clause because of White. ${ }^{117}$ In addition to these alterations in states' judicial codes, some courts have held the pledges or promises clause unconstitutional. ${ }^{118}$

In 2004, the United States District Court for the Eastern District of Kentucky struck down Kentucky's pledges or promises clause as

109. See Appendix infra Part V.

110. See Appendix infra Part V.

111. Model Code OF Judicial Conduct Canon 5(A)(3)(d)(i) (1999) (amended in 2007).

112. See Alexandrea Haskell Young, Note, The First Chink in the Armor? The Constitutionality of State Laws Burdening Judicial Candidates After Republican Party of Minnesota v. White, 77 S. CAL. L. REV. 433, 453 (2004).

113. See Appendix infra Part V.

114. See Republican Party of Minn. v. White, 536 U.S. 765, 770 (2002).

115. Hasen, supra note 54, at 17.

116. See Caufield, supra note 107, at 43.

117. Id. at 41 .

118. See N.D. Family Alliance, Inc. v. Bader, 361 F. Supp. 2d 1021, 1042 (D.N.D. 2005); Family Trust Found. of Ky., Inc. v. Wolnitzek, 345 F. Supp. 2d 672, 696-701 (E.D. Ky. 2004). 
unconstitutionally overbroad. ${ }^{119}$ The court held that the pledges or promises clause was overbroad in that it was not limited to "promises to rule a certain way on issues likely to come before the court"120 but instead prohibited all " "pledges or promises of conduct in office other than the faithful and impartial performance of the duties of the office." "121 The court concluded by stating that Kentucky’s pledges or promises clause prohibited "broad areas of speech the Supreme Court found to be protected in White."122 In 2005, the pledges or promises clause was deleted from Kentucky's judicial code to conform with the district court's holding. ${ }^{123}$

Despite these eliminations of the pledges or promises clause, a majority of the states has retained the pledges or promises clause postWhite, and there have been several decisions explicitly upholding the clause's constitutionality. In 2003, the Supreme Court of Florida upheld Florida's pledges or promises clause, stating that the clause was narrowly tailored to serve the state's compelling interest "in preserving the integrity of our judiciary and maintaining the public's confidence in an impartial judiciary.",124

Also in 2003, the Court of Appeals of New York upheld New York's pledges or promises clause. ${ }^{125}$ The court distinguished the pledges or promises clause from the announce clause, stating that the pledges or promises clause did not restrict candidates from stating their views on legal issues, as long as those statements were not promises "inconsistent with the faithful and impartial performance of judicial duties."126 The court reasoned that such prohibition is necessary because "[j]udges must apply the law faithfully and impartially-they are not elected to aid particular groups, be it the police, the prosecution, or the defense bar. Campaign promises that suggest otherwise gravely risk distorting public perception of the judicial role.”127

\footnotetext{
119. Family Trust, 345 F. Supp. 2d at 696-701.

120. See id. at 696-97.

121. Id. at 676 (quoting Ky. SuP. CT. R. 4.300, Canon 5(B)(1)(c) (amended 2005)).

122. Id. at 703 .

123. See Ky. Sup. CT. R. 4.300, Canon 5(B)(1)(c) cmt. (explaining that section 5(B)(1)(c) was changed in 2005 to conform with White and the district court's holding).

124. In re Kinsey, 842 So. 2d 77, 85-87 (Fla. 2003).

125. In re Watson, 794 N.E.2d 1, 7-8 (N.Y. 2003).

126. Id. at 6.

127. Id. at 7.
} 


\section{b. The Commit Clause}

Although facially narrower than the announce clause, most commit clauses track the language of the Model Code of Judicial Conduct and broadly restrict campaign speech by prohibiting judicial candidates from making "statements that commit or appear to commit the candidate with respect to cases, controversies or issues that are likely to come before the court."128 The commit clause is often compared to the announce clause because, as stated earlier, the commit clause replaced the announce clause language in the 1990 Model Code. ${ }^{129}$ Despite its alleged similarities to the announce clause, some courts have held the commit clause constitutional. ${ }^{130}$ For example, the Florida Supreme Court, which upheld the constitutionality of the pledges or promises clause, also upheld Florida's commit clause as narrowly tailored. ${ }^{131}$ Furthermore, fifteen states, despite the White decision, continue to restrict judicial candidate speech through the commit clause. ${ }^{132}$

The "appear to commit" language of the commit clause is the fuel of the clause's debate. ${ }^{133}$ Three states-California, Georgia, and Pennsylvania-have retained the commit clause but have eliminated the appear to commit language. ${ }^{134}$ Since White, a number of courts have struck down the constitutionality of the appear to commit language. Some believe that because an announcement could appear to commit a judicial candidate to the substance of that announcement, there is no difference between the announce clause and the appear to commit language of the commit clause. ${ }^{135}$ For example, Kentucky and North Dakota, in invalidating their commit clauses, both reasoned that the only difference between the commit clause and the announce clause was their label. ${ }^{136}$

\footnotetext{
128. Model Code OF Judicial Conduct Canon 5(A)(3)(d)(ii) (1999) (amended in 2007).

129. Young, supra note 112, at 452.

130. See, e.g., In re Kinsey, 842 So. 2d 77, 87 (Fla. 2003) (finding that Florida's commit clause "serves a compelling state interest").

131. Id.

132. See Appendix infra Part V.

133. See James Bopp, Jr. \& Anita Y. Woudenberg, An Announce Clause by Any Other Name: The Unconstitutionality of Disciplining Judges Who Fail to Disqualify Themselves for Exercising Their Freedom to Speak, 55 DRAKE L. REV. 723, 752 (2007) (criticizing the "appears to commit" language as "little more than an attempt to reintroduce the ban on announcing views held unconstitutional in White").

134. See Appendix infra Part V.

135. Bopp \& Woudenberg, supra note 133, at 752-53.

136. See N.D. Family Alliance, Inc. v. Bader, 361 F. Supp. 2d 1021, 1042 (D.N.D. 2005); Family Trust Found. of Ky., Inc. v. Wolnitzek, 345 F. Supp. 2d 672, 711 (E.D. Ky. 2004).
} 
In sum, despite the fact that some states are fighting to maintain an impartial judiciary after White, it is clear that White's invalidation of the announce clause sparked a storm in the field of judicial campaign speech regulations and has caused even further deterioration of those regulations.

\section{Judicial Elections and Campaign Expenditures}

Issues sparked by judicial elections involve far more than those surrounding the speech of judicial candidates. Two recent Supreme Court decisions addressed the issues involved with campaign expenditures. First, in Caperton v. A.T. Massey Coal Co., the Court presented recusal as an "impartiality protector" when substantial funds were used by a litigant to place the judge on the bench. ${ }^{137}$ Furthermore, the facts of Caperton provided a powerful warning to the Court of what could become of our elected judiciary if unrestricted amounts of money began to flow into judicial campaigns. Then, in 2010, in Citizens United v. FEC, the Court held that campaign expenditures made on behalf of corporations cannot be restricted. ${ }^{138}$ Unfortunately, the Court ignored Caperton's warning and did not exclude judicial elections from Citizens United's holding. It thus opened the door for substantial corporate treasury funds to buy promises of partial decisions from our "impartial" elected judiciary.

\section{Buckleyv. Valeo}

First, before discussing the recent developments in campaignexpenditures law, it is important to note the Supreme Court's landmark campaign-finance decision: Buckley v. Valeo. The relevant issue in Buckley involved the validity of limitations on campaign contributions and third-party expenditures put into place by the Federal Election Campaign Act Amendments of 1974 (FECA). ${ }^{139}$

The Buckley Court held that spending money on political campaigns, both through contributions and expenditures, is a form of "speech" protected by the First Amendment. ${ }^{140}$ Therefore, the Court subjected the

137. 129 S. Ct. 2252, 2263-64 (2009).

138. 130 S. Ct. 876, 913 (2010).

139. Buckley v. Valeo, 424 U.S. 1, 6-7 (1976).

140. Id. at 57 . 
limitations at issue to strict scrutiny. ${ }^{141}$ In reaching its decision, the Court recognized that the government has an "interest in preventing corruption and the appearance of corruption." ${ }^{142}$ The Court ruled, however, that when balanced against the competing free speech interest, the government interest in preventing corruption carries less weight in the campaign expenditures arena than it does in the campaign contributions arena. ${ }^{143}$ First, the Court concluded that "the reality or appearance of improper influence stem[s] from the dependence of candidates on large campaign contributions" and, therefore, the restrictions on campaign contributions "serve the basic governmental interest in safeguarding the integrity of the electoral process." 144

Conversely, the Court also concluded that the FECA's limitations on campaign expenditures were a much more significant restriction on First Amendment speech. ${ }^{145}$ Furthermore, the Court asserted that independent expenditures by third parties did not result in improper commitments from candidates because they lack the "prearrangement and coordination" involved in campaign contributions. ${ }^{146}$ Thus, the Court held that the FECA's expenditure restrictions were not narrowly tailored to serve the government interest in preventing corruption. ${ }^{147}$

In sum, the Buckley Court upheld FECA's restrictions on campaign contributions but struck down its limits on campaign expenditures, reasoning that independent campaign expenditures do not result in the kind of corruption and appearance of corruption that can result from campaign contributions.

\section{Caperton v. A.T. Massey Coal Co.}

Despite the Court's reasoning in Buckley, the alarming facts of Caperton demonstrate that unrestricted expenditures in judicial elections can result in corruption and, at the very least, the appearance of corruption. In 1998, Hugh Caperton, Harman Development Corp., Harman Mining Corp., and Sovereign Coal Sales (Caperton) filed an action in the Circuit Court of Boone County, West Virginia, against A.T. Massey Coal Co. and its affiliates (Massey) for fraudulent

\footnotetext{
141. See id. at $44-45$.

142. Id. at 45 .

143. Id. at 23 .

144. Id. at 58 .

145. See id. at 19

146. Id. at 47.

147. Id.
} 
misrepresentation, concealment, and tortious interference with existing contractual relations. ${ }^{148}$ The jury found Massey liable, and Caperton was awarded \$50 million in compensatory and punitive damages. ${ }^{149}$ Massey appealed to the Supreme Court of Appeals of West Virginia. ${ }^{150}$

Before the appeal, however, West Virginia held its 2004 judicial elections. ${ }^{151}$ Massey's chairman, Don Blankenship, “[k]nowing the Supreme Court of Appeals of West Virginia would consider the appeal in the case," decided to support a candidate for the Supreme Court of Appeals, Brent Benjamin. ${ }^{152}$ The statutory maximum that Blankenship could contribute to Benjamin's campaign committee was $\$ 1000$. But in addition to the $\$ 1000$, Blankenship donated around $\$ 2.5$ million to "And For The Sake Of The Kids," a political organization that opposed Benjamin's opponent and supported Benjamin. ${ }^{153}$ Moreover, Blankenship spent “just over $\$ 500,000$ on independent expenditures-for direct mailings and letters soliciting donations as well as television and newspaper advertisements” supporting Benjamin. ${ }^{154}$

Benjamin won and Caperton subsequently moved to disqualify him because of "the conflict caused by Blankenship's campaign involvement." " Justice Benjamin denied the motion, and review of the case was granted. ${ }^{156}$ Then, in November 2007, the Supreme Court of Appeals, with Justice Benjamin casting the crucial vote to form the majority, reversed the jury verdict against Massey. ${ }^{157}$

Caperton sought rehearing and moved again to disqualify Justice Benjamin as well as Justice Maynard, who also voted for the majority, because of photos found of Justice Maynard vacationing in the French Riviera with Blankenship while the case was pending. ${ }^{158}$ Massey also moved to disqualify Justice Starcher, who dissented, apparently due to Starcher's public criticism of Blankenship's campaign contributions. ${ }^{159}$ Justice Maynard and Justice Starcher both granted the recusal motions,

\footnotetext{
148. Caperton v. A.T. Massey Coal Co., 679 S.E.2d 223, 233 (W. Va. 2008), rev’d, 129 S. Ct. 2252 (2009).

149. Caperton, 129 S. Ct. at 2257.

150. Id.

151. Id.

152. Id.

153. Id.

154. Id.

155. Id.

156. Id. at 2257-58.

157. See id. at 2258.

158. Id.

159. Id.
} 
and in Justice Starcher's recusal memorandum, he "urged Justice Benjamin to recuse himself as well."160 However, Justice Benjamin denied the recusal motion. ${ }^{161}$ Justice Benjamin sat as chief justice, and Caperton moved a third time to disqualify him, but Justice Benjamin denied the motion yet again. ${ }^{162}$ The court again reversed the jury verdict, and the dissent stated that there were " "genuine due process implications arising under federal law”, because of Justice Benjamin's refusal to withdraw. ${ }^{163}$

The United States Supreme Court granted certiorari to decide whether Justice Benjamin violated the Fourteenth Amendment's Due Process Clause by failing to recuse himself. ${ }^{164}$ The Court held that judges are required to recuse themselves "when a person with a personal stake in a particular case had a significant and disproportionate influence in placing the judge on the case by raising funds or directing the judge's election campaign when the case was pending or imminent." 165 Yet the Court acknowledged that knowing whether a particular contribution caused a judicial candidate's successful election was nearly impossible. ${ }^{166}$ Therefore, the Court determined that "[d]ue process requires an objective inquiry into whether the contributor's influence on the election under all the circumstances" would tempt the judge to abandon judicial duties of impartiality. ${ }^{167}$ Applying this standard to the facts and holding that Benjamin improperly failed to recuse himself, the Court stated:

In an election decided by fewer than 50,000 votes . . . Blankenship's campaign contributions - in comparison to the total amount contributed to the campaign, as well as the total amount spent in the election-had a significant and disproportionate influence on the electoral outcome. And the risk that Blankenship's influence engendered actual bias is sufficiently substantial that it "must be forbidden if the guarantee of due process is to be adequately implemented."168

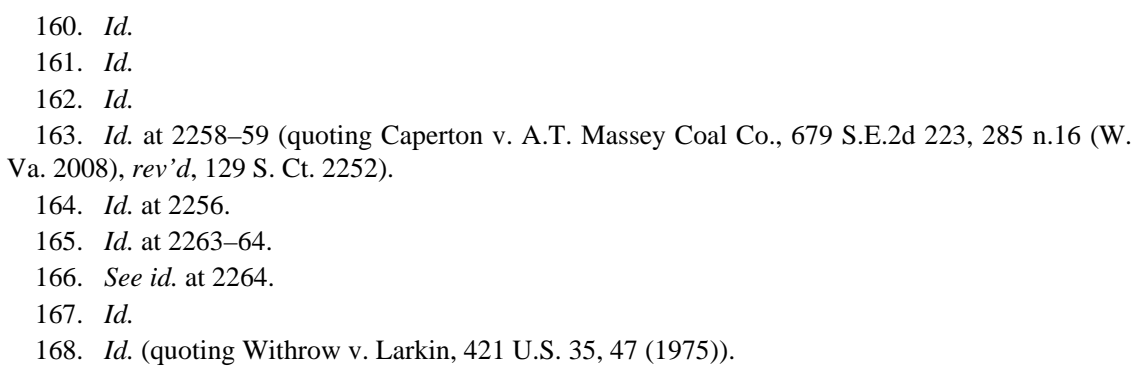


The facts of Caperton proved that, even though expenditures lack the "prearrangement and coordination" involved in campaign contributions, substantial campaign expenditures can result in improper commitments and, thus, corrupt our judiciary. ${ }^{169}$ Unfortunately, the Court's 2010 Citizens United decision disregarded Caperton's warnings and exposed judicial elections to unlimited and influential corporate treasury funds.

\section{Citizens United v. FEC}

In January 2008, Citizens United, a nonprofit organization, released a documentary entitled Hillary: The Movie-which was critical of thenSenator Hillary Clinton-in theaters and on DVD. ${ }^{170}$ Citizens United also wanted to make the documentary available through video-ondemand thirty days before the 2008 presidential primary elections. ${ }^{171}$ However, because Citizens United would have had to pay over \$1 million dollars to make the documentary available through video-ondemand and because Citizens United wanted to promote the video-ondemand option through television advertisements, it feared that it would be banned from doing so under 2 U.S.C. $\S 441 b{ }^{172}$ Section $441 \mathrm{~b}$, as amended by the Bipartisan Campaign Reform Act of 2002 (BCRA), is a federal law that "prohibits corporations and unions from using their general treasury funds to make independent expenditures for speech defined as an 'electioneering communication' or for speech expressly advocating the election or defeat of a candidate."

Therefore, in 2007, Citizens United filed an action in the United States District Court for the District of Columbia seeking declaratory and injunctive relief against the FEC, arguing that $\S 441 \mathrm{~b}$ was unconstitutional as applied to the documentary and that BCRA's disclaimer and disclosure requirements were unconstitutional as applied to the documentary and its ads. ${ }^{174}$ The district court denied Citizens

169. The Appeal, one of John Grisham's bestsellers, is based on the Caperton case. Joan Biskupic, At the Supreme Court, a Case with the Feel of a Best Seller, USA TODAY, Feb. 17, 2009, at $1 \mathrm{~A}$.

170. Citizens United v. FEC, 130 S. Ct. 876, 886-87 (2010).

171. Id. at 888 .

172. Id. at $887-88$.

173. Id. at 886 (citing 2 U.S.C. § $441 \mathrm{~b}$ (2006)).

174. Id. at 888 . 
United's motion and granted summary judgment in favor of the FEC. ${ }^{175}$ The Supreme Court granted certiorari. ${ }^{176}$

After oral arguments, the Court ordered rearguments, asking the parties whether it should overrule two prior cases: Austin v. Michigan Chamber of Commerce and McConnell v. FEC. ${ }^{177}$ In Austin, the Court upheld the Michigan Campaign Finance Act, which prohibited "corporations from using corporate treasury funds for independent expenditures in support of, or in opposition to, any candidate in elections for state office." 178 In holding that the Act did not violate the First or Fourteenth Amendments, the Court stated that "[c]orporate wealth can unfairly influence elections." ${ }^{179}$ In McConnell, the Court relied on Austin and upheld BCRA's limits on corporations' and unions' funding of electioneering communications. ${ }^{180}$ It is important to note, however, that corporations and unions could make campaign contributions and expenditures through separate segregated funds-PACs-consisting entirely of voluntary contributions. ${ }^{181}$

Ultimately, in a five-to-four decision, the Court overruled Austin, striking down $\S 441 \mathrm{~b}$ 's prohibition of independent corporate expenditures. ${ }^{182}$ As a result, the Court also overruled "the part of McConnell that upheld BCRA § 203's extension of § 441b’s restrictions on corporate independent expenditures" to electioneering communications. ${ }^{183}$ In reaching its conclusion, the Court held that $\S 441$ b’s restriction “on corporate independent expenditures [was] a ban of speech" 184 and that "the Government may not suppress political speech on the basis of the speaker's corporate identity."

The government argued that the restrictions on corporate independent expenditures were necessary "to prevent corruption or its appearance." ${ }^{186}$ The Court, however, echoing much of the Buckley

175. Id.

176. See id.

177. Id.

178. Austin v. Mich. Chamber of Commerce, 494 U.S. 652, 654 (1990), overruled by Citizens United, 130 S. Ct. 876.

179. Id. at 660 .

180. See McConnell v. FEC, 540 U.S. 93, 203-09 (2003), overruled by Citizens United, 130 S. Ct. 876.

181. Citizens United, 130 S. Ct. at 887-88.

182. Id. at 913 .

183. Id.

184. Id. at 898.

185. Id. at 913 .

186. Id. at 908 . 
Court's reasoning, concluded that corporate independent expenditures "do not give rise to corruption or the appearance of corruption." 187 The Court stated that just because a corporation has influence "over... elected officials does not mean that these officials are corrupt.”188

The Court did not distinguish "between judicial elections and elections for legislative or executive branch offices," and thus made the Citizens United holding "generally applicable to all elections." "189 For reasons discussed below, however, this is a distinction that should have been drawn. ${ }^{190}$ Furthermore, although the total impact that Citizens United will have on judicial elections is yet to be seen, it will be significant. In his dissent, Justice Stevens expressed his concern for the effect Citizens United will have on judicial elections: "At a time when concerns about the conduct of judicial elections have reached a fever pitch, the Court today unleashes the floodgates of corporate and union general treasury spending in these races."191

Moreover, the same fear that nonpartisan judicial elections sparked-the fear that elections would be determined by "special interests such as insurance companies, big business, labor unions, or segments of the legal profession"192 - has resurfaced by allowing unregulated corporate treasury funds into judicial elections. ${ }^{193}$ Twenty national, regional, and state organizations and a former chief justice of the Georgia Supreme Court explained this fear in an amicus brief filed in Citizens United:

Special interest spending on judicial elections—by corporations, labor unions, and other groups - poses an unprecedented threat to public trust in the courts and to the rights of litigants. This has been recognized and discussed by journalists, academics, and leading jurists, including the Conference of Chief Justices. This Court itself held last term in [Caperton] that some independent expenditures in judicial campaigns are so excessive that they in fact deny litigants due process under the

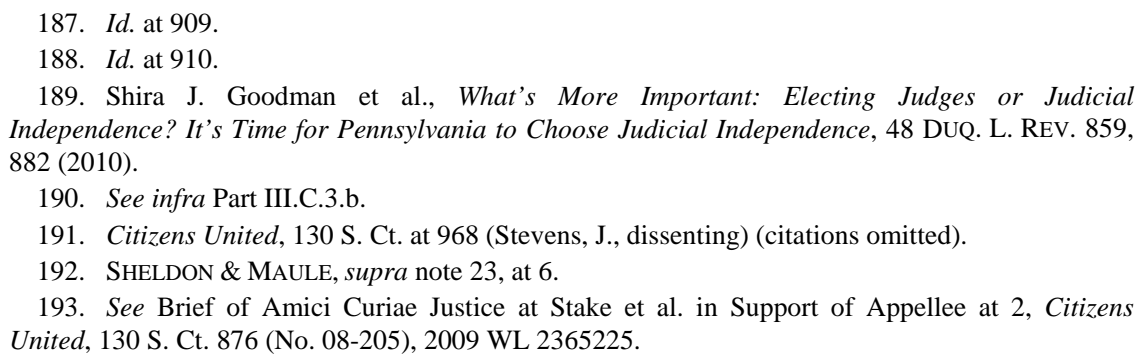


law. If corporate treasury spending were unregulated in judicial elections, these concerns would only get worse. ${ }^{194}$

In sum, before Citizens United, corporations were limited to voluntary contributions from their PACs. Now, however, by allowing corporations to make campaign expenditures from their general treasury funds, Citizens United equips corporations with excessively more power to influence judicial elections. This unregulated power to expend endless amounts of money to ensure that a particular candidate is put on the bench, combined with the substantial deterioration of judicial campaign speech regulations, allows corporations to buy promises of partial decisions, and thus nearly erases the minimal independence left in the elected judiciary.

\section{ANALYSIS}

\section{A. The Role of the Judiciary and Judicial Elections}

As one prominent federal judge has explained: "There is one qualification which is the sine qua non of judicial success or even judicial respectability. That quality is independence."195 The independence of the judiciary is what sets it apart from other branches of government. The judiciary must not act as anyone's or anything's agent and should "not be swayed by public clamor"196 but, instead, should "perform all duties of judicial office fairly and impartially.",197 Ironically, judicial elections, which were adopted as an attempt to provide the judiciary with more independence, have depreciated the judiciary's independence. ${ }^{198}$ What began as an effort to ensure that judges were not agents of the legislature served as the catalyst that morphed elected judges into agents of the electorate. ${ }^{199}$ Judicial elections have transformed our impartial keepers of justice into politicians. Judge John Parker, who was Senior Judge of the United States Circuit Court of Appeals for the Fourth Circuit, stated in 1947: "To see, as I have seen, a candidate for the judgeship advertising his candidacy and soliciting the support of all sorts of politicians ... is a sight to make the angels

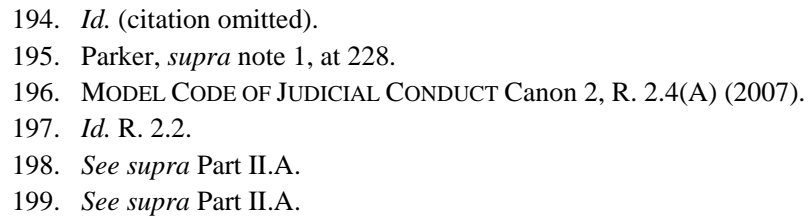


weep.”200 In her White concurrence, Justice O'Connor argued that judicial election regulations were not the primary concern but that "the very practice of electing judges undermines” an impartial judiciary. ${ }^{201}$

Opponents of judicial elections have looked towards judicial campaign regulations as a possible means to minimize the risk of further diminishing impartiality. ${ }^{202}$ Unfortunately, several decisions throughout the past decade have chipped away at these regulations to the point that judicial elections seem almost no different from legislative elections. Many have begun to feel that "justice is for sale." ${ }^{203}$ Arguably, from a "consumer" standpoint, it would be cheaper to purchase a few judges than it would be to buy an entire legislature. An Ohio Supreme Court justice told the New York Times, "I never felt so much like a hooker down by the bus station . . . as I did in a judicial race.",204

However, “'[j]udicial reform is no sport for the short-winded,",205 and judicial elections do not seem to be disappearing anytime soon. Therefore, those who are unflinchingly holding on to hope that the judiciary will one day reflect the impartiality our nation's founders had in mind when they opted for judicial appointments should continue to focus on rebuilding what have become almost meaningless campaign regulations.

\section{B. The Constitutionality of Prohibiting Promissory Campaign Statements}

As discussed earlier, a majority of the states that regulate judicial campaign speech do so by prohibiting judicial candidates from making certain pledges, promises, and-in twenty-two of those statescommitments. ${ }^{206}$ Furthermore, three of the states that have retained the commit clause have eliminated the "appear to commit" language, thus only prohibiting "statements that commit." 207 When a candidate pledges,

200. Parker, supra note 1 , at 234.

201. Republican Party of Minn. v. White, 536 U.S. 765, 788 (2002) (O’Connor, J., concurring).

202. See supra Part II.A-B.

203. Deborah Goldberg, Public Funding of Judicial Elections: The Role of Judges and the Rules of Campaign Finance, 64 OHIO ST. L.J. 95, 95 (2003).

204. Adam Liptak \& Janet Roberts, Campaign Cash Mirrors a High Court's Ruling, N.Y. TIMES, Oct. 1, 2006, at A1 (quoting Ohio Supreme Court Justice Paul E. Pfeifer).

205. Kelley Armitage, Denial Ain't Just a River in Egypt: A Thorough Review of Judicial Elections, Merit Selection and the Role of State Judges in Society, 29 CAP. U. L. REV. 625, 626 (2002) (quoting Charles HenNing, THE WIT \& Wisdom OF POLITICS 107 (1989)).

206. See Appendix infra Part V.

207. See Appendix infra Part V. 
promises, or commits, he or she presumably intends to do so and is aware of that pledge, promise, or commitment. Thus, these judicial codes are prohibiting promissory statements—statements "containing or conveying a promise or assurance.”208 For reasons discussed below, prohibiting judicial candidates from making certain promissory statements does not violate the First Amendment.

\section{Pledges and Promises}

For those states that have retained some form of restrictions on judicial campaign speech regarding candidates' views on specific legal issues, the narrowest speech regulation is the pledges or promises clause. $^{209}$ Courts that have struck down the clause heavily rely on the Supreme Court's reasoning in White. ${ }^{210}$ White's reasoning, however, is a strong argument for the constitutionality of the pledges or promises clause.

First, the White Court explicitly stated that “'announc[ing] . . views' on an issue covers much more than promising to decide an issue a particular way."211 The Eastern District of Kentucky's conclusion that the pledges or promises clause prohibits the same speech that the Court labeled as protected in White is completely invalidated by the White Court's repeated distinction between promissory and nonpromissory statements and the Court's suggestion that promissory statements could plausibly impair impartiality. ${ }^{212}$

Moreover, even without consideration of White's distinction between announcements and promises, the White framework still renders the pledges or promises clause constitutional. First, the clause satisfies the compelling-state-interest prong of strict scrutiny. In White, the Court played with the idea of "openmindedness" being a compelling state interest but ultimately left the question unanswered because Minnesota did not define impartiality as openmindedness. ${ }^{213}$ It is difficult to argue, however, that a state would not have a compelling state interest in an openminded judiciary. Furthermore, the ABA and twenty of the twenty-

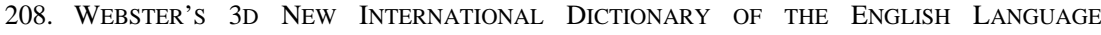
UNABRIDGED 1815 (1981).

209. See supra Part II.B.2.

210. See supra Part II.B.2.a.

211. Republican Party of Minn. v. White, 536 U.S. 765, 770 (2002) (quoting MinN. CoDE OF JUDICIAL CONDUCT Canon 5(A)(3)(d)(i) (2002) (abrogated 2009)).

212. See id. at 780-81.

213. Id. at 778 .
} 
eight states that have a pledges or promises clause in their judicial code have defined impartiality as the maintenance of an open mind. ${ }^{214}$

Additionally, based on White's reasoning in holding that the announce clause was not narrowly tailored to promote openmindedness, the pledges or promises clause is narrowly tailored to promote openmindedness. The White Court reasoned that the announce clause was not narrowly tailored because it permitted judicial candidates to announce their views on disputed legal issues right up to the start of a campaign. $^{215}$ However, clearly distinguishable from a prospective judicial candidate announcing his view on a particular legal issue before the start of a campaign, a prospective judicial candidate- outside of a judicial campaign - would have no reason to make a promise about future issues likely to come before a particular court. Moreover, a promise made during a judicial campaign is particularly bothersome because the candidate makes it for the purpose of being elected to the bench. Because judicial candidates have yet to be elected, their promissory statements are asserting: "If you elect me to the bench, I promise $x, y$, and $z$." There would be no reason for such a statement outside of the campaign arena. For these reasons, the pledges and promises clause is narrowly tailored to serve the compelling state interest of openmindedness, and, thus, it is constitutional to prohibit judicial candidates from making certain promises and pledges.

\section{Commitments and Statements That Commit}

Twenty-two of the states that regulate judicial campaign speech through the pledges and promises clause have added the word "commitments" to prohibit judicial candidates from making "pledges, promises, and commitments that are inconsistent with the impartial performance" of judicial duties. ${ }^{216}$ Generally, this addition to a state's

214. Model Code of Judicial Conduct Terminology (2007); ARIz. SuP. CT. R. 81, Terminology; ARK. CODE of Judicial CONDUCt Terminology; Colo. CODE OF Judicial CONDUCT Terminology; Fla. Code of Judicial Conduct Definitions; Haw. Rev. Code of Judicial CONDUCT Terminology; Ind. CODE of JudiCial ConduCt Terminology; Kan. SuP. CT. R. 601B, Terminology; MD. RUles R. 16-813, Terminology; MinN. CODE OF JUdiCiAL CONDUCT Terminology; Mont. Code of Judicial Conduct Terminology; Nev. Code OF Judicial Conduct Terminology; N.H. SuP. CT. R. 38, Terminology; N.M. SUP. CT. R. 21-001(D); N.Y. CT. R. $\S 100.0(\mathrm{R}) ;$ N.D. CODE OF Judicial CONDUCT Terminology; OHIO CODE OF JUdicial CONDUCT Terminology; S.D. CODE OF JUdiCIAL CONDUCT Terminology; UTAH CODE OF JUdiCIAL CONDUCT Terminology; WIS. SUP. CT. R. 60-01(7m); WYO. CODE OF JUDICIAL CONDUCT Terminology.

215. White, 536 U.S. at 779-80.

216. See Appendix infra Part V (emphasis added). 
pledges or promises clause is the result of other alterations in the judicial code, such as eliminating the commit clause. ${ }^{217}$ Yet some have asserted that the addition of commitments to the pledges or promises clause transforms the clause to a commit clause. ${ }^{218}$

In Kansas Judicial Review v. Stout, a Sedgwick County judicial candidate challenged the constitutionality of Kansas's pledges or promises clause and commit clause. ${ }^{219}$ However, before the case was decided, the Kansas Supreme Court amended the state's judicial code. ${ }^{220}$ The amendment deleted the code's commit clause ${ }^{221}$ and added the word commitments to its pledges or promises clause. ${ }^{222}$ When the Tenth Circuit held that this amendment rendered the case moot, the plaintiffs argued that the campaign speech regulations were still unconstitutional. ${ }^{223}$

The plaintiffs contended that even though pledge, promise, and commit facially appear to have the same meaning, the addition of commitments points towards an intention to expand the meaning of the pledges or promises clause. ${ }^{224}$ The Kansas Supreme Court, however, concluded that “'[c]ommit' connotes a similar meaning to 'pledge' or 'promise." "225 Thus, the addition of commitments to the pledges or promises clause did not broaden the scope of the original pledges or promises clause and merely reinforced the idea that judicial candidates cannot bind themselves to a "particular disposition with regard to a particular issue."226

At this point, it is important to note that there is no arguable difference between a commitment and a statement that commits. Thus, it follows from the above discussion - which equated pledges and promises to commitments - that there is no distinguishable difference between a pledges or promises clause and a commit clause that has eliminated the appear to commit language and merely prohibits "statements that commit.”

217. See supra Part II.B.2.b.

218. See Supplemental Response Brief of Plaintiffs-Appellees at 8, Kan. Judicial Review v. Stout, 562 F.3d 1240 (10th Cir. 2009) (No. 06-3290), 2009 WL 383288.

219. Stout, 562 F.3d at 1243-44.

220. Id. at 1245.

221. KAN. Sup. Ct. R. 601A, Canon 5(A)(3)(d)(ii) (superseded 2009).

222. KAN. SUP. CT. R. 601B, Canon 4, R. 4.1(A)(6).

223. Stout, 562 F.3d at 1246.

224. Supplemental Response Brief of Plaintiffs-Appellees, supra note 218, at 8.

225. Kan. Judicial Review v. Stout, 196 P.3d 1162, 1175 (Kan. 2008).

226. Id. 
In sum, judicial codes that prohibit certain pledges, promises, commitments, and statements that commit are all prohibiting the same thing: promissory statements. Furthermore, prohibiting judicial candidates from making certain promissory statements is constitutional because such prohibition is narrowly tailored to serve the compelling state interest of openmindedness. Not only is the prohibition of promissory statements constitutional, but the added power that Citizens United gives to "special interests" to control judicial elections renders it necessary to prohibit judicial candidates from seeking support by making promises about future conduct.

\section{The Constitutionality and Necessity of the Announce Clause}

Part III.B established that it is constitutional for states to prohibit judicial candidates from making promissory statements about issues likely to come before the court. Yet under White, it is unconstitutional to prohibit judicial candidates from making nonpromissory statements. Now, however, after Citizens United, unregulated campaign spending from corporations' treasury funds can convert nonpromissory campaign statements into implied promissory statements, which are inconsistent with the impartiality of our judiciary. Therefore, to maintain the impartiality of our judiciary, White and Citizens United cannot live together.

\section{The Announce Clause's Unconstitutionality Pre-Citizens United}

Before Citizens United, the Supreme Court correctly concluded in White that states cannot prohibit judicial candidates from announcing their views on disputed legal issues. ${ }^{227}$ For example, it would unnecessarily circumscribe protected expression if the public was simply curious about a candidate's view on sex-offender sentencing laws and the candidate could not announce his view purely for the purpose of fulfilling the public's curiosity.

Unfortunately, the foul reality that courts continue to tiptoe around is that no judicial candidate would announce his views on a disputed legal issue without the motive of securing votes. Furthermore, no voting citizen would receive the announcement without interpreting it as an indication of how the candidate would carry out his duties if elected. Many were dissatisfied with the 1972 Model Code's elimination of the

227. See supra Part II.B.1. 
"to secure class support" language from the announce clause, ${ }^{228}$ arguing that the elimination broadened the clause's scope. ${ }^{229}$ However, it is entirely naïve to think that a judicial candidate would announce his stance on an issue without the purpose of securing votes.

Disappointingly, because courts have yet to acknowledge this pink elephant in the judicial campaign arena and because there is no reliable way of proving a candidate's motive behind a campaign statement, the Court correctly held that prohibiting nonpromissory campaign statements violated the First Amendment rights of judicial candidates.

\section{Citizens United's Invalidation of White}

In 2010, when the Supreme Court concluded in Citizens United that the First Amendment prohibited restrictions on corporate campaign expenditures, it created a need for courts to acknowledge the reality behind nonpromissory judicial campaign statements. ${ }^{230}$ If the judiciary is to reflect even the slightest degree of the impartiality that is the sine qua non of judicial success, it is hard to imagine how White and Citizens United can live together.

White rests on the notion that the announce clause is unconstitutional because a nonpromissory campaign statement is not uniquely destructive of impartiality. After Citizens United, however, it is clearer than ever that what begins as a nonpromissory campaign statement can effortlessly transform into an implied promise that is inconsistent with the impartial performance of judicial duties. For example, before Citizens United the campaign statement, "I think the previous court's verdicts in products liability cases were far too excessive," would be deemed a nonpromissory campaign statement, and although the candidate would clearly have a motive to secure votes by making the statement, he could not constitutionally be prohibited from doing so. Now, however, if a judicial candidate made that statement and a large insurance company subsequently expended a great deal of money to put out several advertisements for the candidate or against the candidate's opponent, the nonpromissory campaign statement transforms into an implied promise to the insurance company to minimize verdicts in products liability cases.

This implied transformation is rooted in the politics that have become so intertwined with judicial elections. After the White decision,

228. See Model Code of Judicial Conduct Canon 7(B)(1)(c) (1972) (amended 2007).

229. MCFADDEN, supra note 34, at 86.

230. See supra Part II.C.3. 
then-ABA president Robert Hirshon stated that " "now we are going to have judicial candidates running for office by announcing their position on particular issues. They will know that the voters will evaluate their performance in office on how closely their rulings comport with those positions." "231 Hirshon's concerns are now multiplied by the pressure and indebtedness judges naturally will feel towards those corporations and organizations that make substantial expenditures on the judicial candidate's behalf.

Furthermore, in addition to indebtedness, a judicial candidate may be fearful of the repercussions that will follow from contradicting the campaign statement. For example, the judicial candidate supported by the insurance company may not want to hand down a substantial verdict, regardless of special circumstances involved in the case, out of fear of losing the insurance company's support-or gaining the company's opposition - in a future re-election campaign.

Additionally, these ramifications of Citizens United provide corporations with an unacceptable degree of power in the law-making process. Part of the motivation behind the merit system of judicial appointments and retention was the fear produced by nonpartisan elections that close races would be decided by "special interests."232 This fear is especially valid when coupled with the White Court's acknowledgement of an uninformed electorate. ${ }^{233}$ Because the general public knows little about judicial qualifications, an uninformed citizen is likely - when choosing between two judicial candidates she knows little about - to vote for the judge she remembers seeing the insurance company's advertisements for, or maybe even more understandably, not vote for the judge she saw advertisements against. Because of the indebtedness and dependence judges may feel to corporations and organizations that quite obviously had a lot to do with putting those judges on the bench, not only will special interests be deciding races but they will be deciding law.

The pressure, indebtedness, fear, and dependence that Citizens United will place on elected judges entirely undermines the impartiality of the judiciary. Citizens United has inflicted upon us the injustice that our nation's founding fathers sought to avoid. John Marshall stated during a debate on the Virginia Constitution:

231. Caufield, supra note 107, at 39 (quoting Dan Margolies, Ruling Throws a Wrench into the Missouri Plan, KAN. CiTY STAR, July 16, 2002, at D18).

232. SHELDON \& MAULE, supra note 23, at 6.

233. Republican Party of Minn. v. White, 536 U.S. 765, 773 (2002). 
The Judicial Department comes home in its effects to every man's fireside: it passes on his property, his reputation, his life, his all. Is it not, to the last degree important, that he [the judge] should be rendered perfectly and completely independent, with nothing to influence or controul him but God and his conscience? ...

... I have always thought, from my earliest youth till now, that the greatest scourge an angry Heaven ever inflicted upon an ungrateful and a sinning people, was an ignorant, a corrupt, or a dependent Judiciary. ${ }^{234}$

Therefore, something must be done to correct what a decade of decisions, capped off by Citizens United, has slowly converted our impartial judiciary into: an indebted, influenced, and dependent judiciary.

\section{Severing White and Citizens United}

\section{a. Overruling White}

The first, but most unlikely and unrealistic, solution would be to overrule White. But while it is unlikely, there is still a strong argument to be made for overruling White to correct the injury to judicial impartiality that Citizens United has caused. Without campaign announcements of views on disputed legal issues, elected judges will not be tempted to sway away from impartiality to avoid contradicting their campaign statements. Before Citizens United an elected judge still could have felt hesitation about contradicting a past statement, just as any human being does. Now, however, with the added pressure, indebtedness, dependence, and fear caused by substantial expenditures made by special interests, surrendering to the temptation to avoid contradicting a campaign statement will be almost automatic_-regardless of impartiality considerations. Therefore, prohibiting judicial candidates from making such statements is an obvious solution.

Despite the effectiveness of overruling White, the doctrine of stare decisis renders it an unlikely and unrealistic solution. The Court has reiterated many times, however, that stare decisis "is a rule of policy, not

234. Proceedings and Debates of the Virginia State Convention of 1829-30, at 616, 619 (Richmond, Samuel Shepherd \& Co. 1830). 
a rule of law." ${ }^{235}$ In Planned Parenthood of Southeastern Pennsylvania v. Casey, the Court identified four "prudential and pragmatic" factors to balance when deciding whether to overrule a prior decision: (1) "whether the rule has proven to be intolerable simply in defying practical workability," ${ }^{236}$ (2) "whether the rule is subject to a kind of reliance that would lend a special hardship to the consequences of overruling,",237 (3) "whether related principles of law have so far developed as to have left the old rule no more than a remnant of abandoned doctrine," ${ }^{238}$ and (4) "whether [the rule's] premises of fact have so far changed... as to render its central holding somehow irrelevant or unjustifiable in dealing with the issue it addressed."239

The last factor listed by the Casey Court, whether White's premises of "fact have so changed, or come to be seen so differently, as to have robbed the old rule of significant application or justification,"240 appears to provide the strongest basis for overruling White. Citizens United has so changed White's premises of fact as to rob White of its justification. First, in White, the majority concluded that "lack of bias for or against either party to a proceeding" was a compelling state interest but that the announce clause was not narrowly tailored to serve that interest because it restricted speech about issues, not parties. ${ }^{241}$ Justice Scalia reasoned that when an issue comes before a judge-which the judge took a particular stance on during his campaign - "the party taking the opposite stand is likely to lose. But not because [of] . . f favoritism toward the other party.... [Rather, $t$ ]he judge is applying the law (as he sees it) evenhandedly."242

Now, however, Citizens United's substantial expenditures make the distinction between opinions on legal issues and favoritism towards particular parties incredibly murky. For example, before Citizens United, if the judge who made the campaign statement, "I think the previous court's products liability verdicts were too excessive," hands down less substantial verdicts, it is hard to argue that he is doing so because of favoritism towards the defendants. Now, however, with a large

235. Michael Stokes Paulsen, Abrogating Stare Decisis by Statute: May Congress Remove the Precedential Effect of Roe and Casey?, 109 YALE L.J. 1535, 1537 \& n.1 (2000).

236. Planned Parenthood of Se. Penn. v. Casey, 505 U.S. 833, 854 (1992).

237. Id.

238. Id. at 855 .

239. Id.

240. Id.

241. Republican Party of Minn. v. White, 536 U.S. 765, 776-77 (2002).

242. Id. 
insurance company's substantial campaign expenditures, the judge's less substantial verdicts begin to look less like an evenhanded application of the law and more like favoritism towards the insurance company or bias against the company's "opponents."

Secondly, the White Court determined that the announce clause unnecessarily circumscribed protected expression; however, the addition of Citizens United to White unnecessarily harms the administration of justice. The perfect balance appears impossible to ascertain, but when there is a conflict between the protections of those rendering justice and those seeking justice, the scales should give way to the seekers. Surely, a litigant's right to justice is more fundamental than a judicial candidate's right to announce his opinions. The added hit of Citizens United, and its conversion of nonpromissory statements into implied promises, unnecessarily harms the independence of our judiciary and renders the announce clause necessary.

The changed circumstances since White-Citizens United-also provide an argument under another factor identified by the Casey Court: workability. ${ }^{243}$ When deciding whether to overrule White, the Court should "enquire whether [White's] central rule has been found unworkable." 244 The Court has defined workability as an issue of "judicial competence."245 Here, White has required judicial assessment of state judicial codes affecting candidates' ability to make nonpromissory campaign statements, and these determinations have not incontestably "fall[en] within judicial competence."246 As discussed above, distinguishing between announcements and commitments has been an area of grief and disagreement for the courts. ${ }^{247}$ Now, with the added effect of Citizens United's substantial campaign expenditures converting nonpromissory campaign statements into implied promises, the line between announcements and commitments will be even more difficult for courts to ascertain. Therefore, the unworkability of White's holding weighs in favor of overruling White.

Another factor the Casey Court instructs us to consider is whether overruling White can be done "without serious inequity to those who have relied upon it or significant damage to the stability of the society governed by it."248 The backbone of this inquiry is whether the White

\footnotetext{
243. Casey, 505 U.S. at 855.

244. Id.

245. Id.

246. Id.

247. See supra Part II.B.2.b.

248. Casey, 505 U.S. at 855.
} 
holding "has created substantial investment-backed expectations, such that shifting it would feel like Lucy pulling the football away from Charlie Brown, once the full force of his leg and body had become invested in the legitimate expectation of kicking it.,249

Here, there is obviously an argument for maintaining White. Presumably, both the electorate and judicial candidates have understandably come to rely on the ability of candidates to announce their views on disputed legal issues. However, the real argument would be whether those expectations are substantially investment-backed. The answer to that question would be difficult to ascertain and vary considerably from state to state and election to election.

Furthermore, the amount of weight that should be given to this factor does not seem substantial. The Court has made it clear that prior decisions can be overruled - the law can change-even if doing so "disturb[s] the relied-upon expectations of individuals."250 Concern for disrupting expectations cannot control our law-making process. "The simple fact is that legal rules change all the time. Legislatures are constantly creating new legal rules.... Only a fool or a sucker-like Charlie Brown relying on Lucy-would count on the legal rule remaining firmly in place.”251

Despite the sharp conflict between White and Citizens United, as well as the strong arguments weighing in favor of overturning White, there are other arguments that cut against overruling White. The final factor that Casey instructs us to consider is "whether the law's growth in the intervening years has left [White's] central rule a doctrinal anachronism discounted by society."252 This consideration does not weigh in favor of overturning White since White's holding has clearly not become a "doctrinal anachronism discounted by society."

Furthermore, the current composition of the Court points towards the retention of White. Since Justice Alito's replacement of Justice O'Connor, the Court has "struck down or narrowed campaign regulations that the Court 'clearly would have upheld had O'Connor been on the court.",253 Lastly, the principle of stare decisis is strongly rooted in our

249. Michael Stokes Paulsen, Does the Supreme Court's Current Doctrine of Stare Decisis Require Adherence to the Supreme Court's Current Doctrine of Stare Decisis, 86 N.C. L. REV. 1165, 1178 (2008).

250. United States v. Carlton, 512 U.S. 26, 34 (1994).

251. Paulsen, supra note 249, at 1178-79.

252. Casey, 505 U.S. at 855.

253. Stephen Dinan, O’Connor Exit Set Stage for Campaign-Ad Ruling, WASH. TimES, Jan. 22, 2010, at A12 (quoting Professor Richard Briffault of Columbia Law School); see also Grant Fevurly, 
judicial system, and the Court rarely overturns itself. ${ }^{254}$ Therefore, overruling White appears an unlikely and unrealistic solution.

\section{b. Excluding Judicial Elections from Citizens United}

A second-and arguably stronger-solution to Citizens United's negative impact on the judiciary is to exclude judicial elections from the application of Citizens United. The Citizens United majority did not discuss the holding's impact on the judiciary. ${ }^{255}$ In fact, the majority did not mention the judiciary at all in its opinion. ${ }^{256}$ Furthermore, while there is little case law discussing the constitutional protection of expenditures specifically in judicial elections, the distinct differences between the judiciary and the other branches of government justify greater restrictions on spending in the judicial campaign arena.

First, judges do not fall within the same "representative politics" as legislative and executive officials. Before expanding on this idea, however, a discussion about the courts' role as policymakers is necessary. Although the primary role of the judiciary is to impartially decide disputes between parties according to the law, the idea that judges merely "find the law" is more of a myth than a reality. Because the "law remains one of the most common means of formalizing public policy," judges are not only impartial arbitrators but policymakers as well. ${ }^{257}$ Judges shape and develop the law every time they rule on the meaning of a statute.

But despite the courts' role as policymakers, the judiciary is fundamentally a different kind of policymaker — and therefore a different kind of representative- -than the legislature. The distinction between the judiciary and other "representative politics" is one that does not go unsupported. As Judge Cardozo once described the policymaking difference between the legislature and the judiciary, the judiciary "legislates only between the gaps."258 Dissenting in White, Justice

Note, Davis v. Federal Election Commission: A Further Step Towards Campaign Finance Deregulation and the Preservation of the Millionaires' Club, 81 U. CoLO. L. REv. 627, 643 (2010) (discussing the judicial shift after O’Connor was replaced); Daphne Eviatar, Supreme Court Eyes Decades of Campaign Finance Laws, WASH. INDEP. (Sept. 8, 2009, 6:00 AM), http://washington independent.com/57983/supreme-court-eyes-decades-of-campaign-finance-laws (same).

254. Michael J. Gerhardt, How a Judge Thinks, 93 MinN. L. REV. 2185, 2197 (2009) (reviewing RiCHARD A. POSNER, HOW JUdGES THINK (2008)).

255. See Citizens United v. FEC, 130 S. Ct. 876, 916-17 (2010).

256. See supra Part II.C.3.

257. WALTER F. MURPhy, ElEMENTS OF JUdicial Strategy 1 (1964).

258. Benjamin N. Cardozo, The Nature of the Judicial Process 113 (1921) (emphasis 
Ginsburg asserted that the difference between the judiciary's representative function and that of other braches of government is rooted in the fact that "[e]ven when [judges] develop common law or give concrete meaning to constitutional text, judges act only in the context of individual cases, the outcome of which cannot depend on the will of the public."259 Therefore, Justice Ginsburg concluded, "[l]egislative and executive officials act [as representatives] of the voters who placed them in office; 'judge[s] represen[t] the Law.' "'260

Still, whether the current Court would distinguish the judiciary from other "representative politics" is not entirely clear. In Chisom v. Roemer, the Court held that judges were "representatives" within the meaning of section 2 of the Voting Rights Act. ${ }^{261}$ Justice Stevens-considered by many to have been on the liberal side of the Court ${ }^{262}$ - wrote for the majority in Chisom and reasoned that the very act of electing judges places the judiciary in the same category of "representatives" as the other branches of government. ${ }^{263}$ Then, however, in Stevens's White dissent, he asserted that the judiciary is "fundamentally different from [the office] occupied by policymaking officials."264 Justice Souter joined Justice Stevens in both Chisom and White. ${ }^{265}$

Conversely, Justice Scalia-who sits on the conservative side of the Court-dissented in Chisom, contending "it is the prosecutor who represents 'the People'; the judge represents the Law."266 Yet writing for the majority in White, Scalia asserted that the "separation of the judiciary from the enterprise of 'representative government'" had become greatly exaggerated. $^{267}$ Chief Justice Rehnquist and Justice Kennedy joined Justice Scalia in both Chisom and White. ${ }^{268}$

Nevertheless, even if the current Court would agree with the Chisom majority that judicial elections place the judiciary within the scope of "representative politics," there are still several arguments to be made for

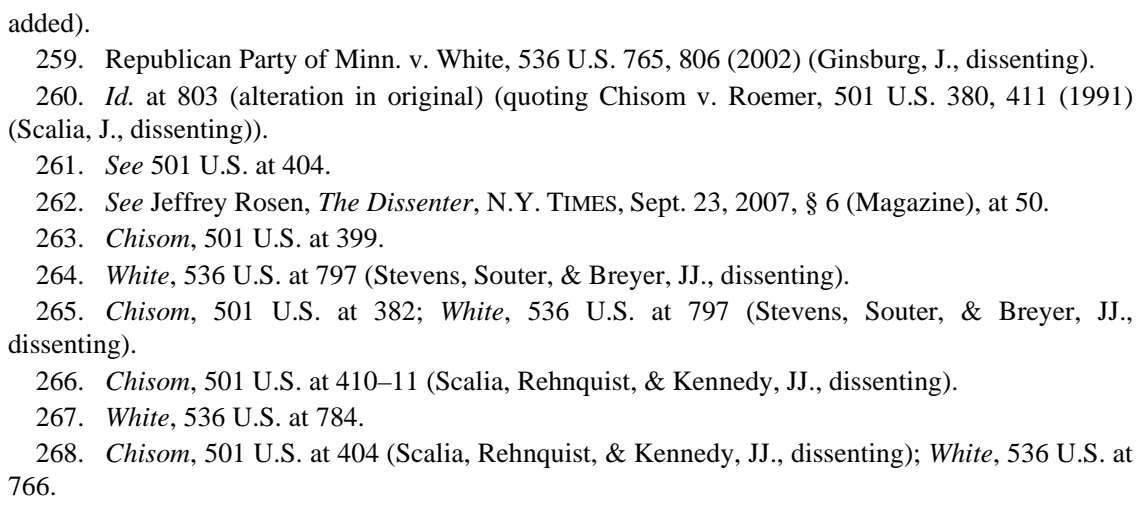


excluding judicial elections from Citizens United's holding. First, the majority's reasoning in Citizens United is contradictory to the characteristics of our impartial judiciary. The majority reasons that "favoritism and influences are not... avoidable in representative politics" and that just because corporations "have influence over... elected officials does not mean that those officials are corrupt.,"269 Based on this reasoning, it is hard to understand Citizens United's application to judicial elections. The Citizens United majority recognized that a consequence of its holding would be corporate influence; however, contrary to what the Court stated, an influenced judiciary is a corrupt judiciary by definition.

Secondly, judicial elections already differ from legislative and executive elections in ways that have major consequences on spending in judicial elections. For example, "[o]ther elective officials are free to seek support by making promises about how they will perform. Judges are not." 270 Additionally, for many years polls have evidenced that voters are terrifically uneducated in judicial elections, not knowing even the names of "the most visible judicial candidates."271 Our electorate's lack of education in judicial elections buttresses the fear that "special interests," funded by substantial corporate expenditures, will be deciding races. $^{272}$

Lastly, courts recognize the view that judicial elections should be treated discretely from other elections because of the judiciary's unique characteristics. For example, the Kansas Supreme Court has recognized that "the judicial candidate is forbidden to enter [the] customary campaign arena." 273 Even the Supreme Court, in White, made a point to clarify that it was not asserting or implying "that the First Amendment requires campaigns for judicial office to sound the same as those for legislative office."274

In sum, even though judges are policymakers-and despite the assertion made by some that the judiciary falls within the scope of "representative politics" - the inherent differences between the judiciary

269. Citizens United v. FEC, 130 S. Ct. 876, 910 (2010) (emphasis added).

270. Roy A. Schotland, Campaign Finance in Judicial Elections, 34 LoY. L.A. L. REV. 1489, 1490 (2001).

271. Roy A. Schotland, Financing Judicial Elections, 2000: Change and Challenge, 2001 MicH. ST. L. REV. 849, 855 \& n. 26.

272. See generally Todd E. Pettys, Letter from Iowa: Same-Sex Marriage and the Ouster of Three Justices, 59 U. KAN. L. REV. 715 (2011) (describing all of the groups that funded the campaign against the retention of three Iowa justices).

273. In re Baker, 542 P.2d 701, 705 (Kan. 1975).

274. Republican Party of Minn. v. White, 536 U.S. 765, 783 (2002). 
and the other branches of government justify excluding judicial elections from Citizens United's holding. This conclusion would, of course, eliminate the concerns for the judiciary's independence that Citizens United has caused.

c. In the Meantime

To restore and maintain the impartiality of our judiciary, White and Citizens United cannot live together. If White and Citizens United are not separated, either by overturning White or by excluding judicial elections from Citizens United's holding, judicial candidates' nonpromissory campaign statements will be downgraded to promises to the "special interests" willing to spend the most. Still, until the severance of White and Citizens United is accomplished-if ever-states should protect the impartiality of their judiciaries by increasing their recusal standards.

The facts of Caperton-big money purchasing a particular judge and, thus, particular rulings_-provide a painfully realistic example of what could become of our judiciary. ${ }^{275}$ Unfortunately, the Caperton requirement that judges recuse themselves when a "contributor's influence on the election under all the circumstances" would tempt the judge to abandon judicial duties of impartiality ${ }^{276}$ does not provide adequate safeguards against the risks to our judiciary. In fact, the Court emphasized that the facts of Caperton were "extreme" and held that its decision only applied to "extraordinary situation[s]" like Caperton. ${ }^{277}$ Furthermore, the Court recognized the inadequacy of due process recusal standards and noted that state judicial codes provide more protection than due process. ${ }^{278}$

Therefore, states should begin to battle the breakdown of our impartial judiciary through rigorous recusal laws. For example, the ABA's recusal standard requires judges to recuse themselves when a judicial candidate makes a public statement that "appears to commit the judge to reach a particular result." 279 Whether substantial expenditures

275. See supra Part II.C.2.

276. See Caperton v. A.T. Massey Coal Co., 129 S. Ct. 2252, 2263-64 (2009).

277. Id. at 2265 .

278. Id. at 2265-67.

279. Model Code of Judicial Conduct Canon 2, R. 2.11(A)(5) (2007). Reform of state recusal laws is beyond the scope of this Comment. For further discussion on the topic, see Jason D. Grimes, Note, Aligning Judicial Elections with Our Constitutional Values: The Separation of Powers, Judicial Free Speech, and Due Process, 57 CLEV. ST. L. REV. 863, 885 \& n.170 (2009). 
were made by a "special interest" - related to the public statementcould factor into whether the statement "appeared to commit" the candidate. Yet the strengthening of recusal laws is bound to raise a new set of constitutional issues and flaws. For example, would judicial candidates begin to self-censor so much that the recusal laws would become restrictive of protected speech? Thus, although states should begin to implement more rigorous recusal standards to protect their judiciary, this response will not take away from the pressing need to sever White and Citizens United from each other.

\section{CONCLUSION}

The judiciary is far different than any other branch of our government. Our judges are to act as agents of justice, and justice alone. Unfortunately, decisions throughout the past decade have defeated almost all efforts to ensure the independence of our elected judiciary. If jurisdictions that select judges through elections plan to rebuild and maintain an impartial judiciary, the first step is to ensure that special interests are not buying up and controlling judges - which is exactly what the intersection of White and Citizens United has made possible.

In striving for an impartial judiciary, White and Citizens United cannot live together. By placing feelings of pressure, indebtedness, fear, and dependence into the minds of judicial candidates who were put on the bench largely due to substantial campaign expenditures by corporations, Citizens United takes what White described as nonpromissory campaign statements that are not uniquely destructive of impartiality and converts those statements into implied promisespromises that threaten the litigant's right to impartial justice. Therefore, something must be done. The conflict between White and Citizens United must be eliminated. As such, White and Citizens United must be severed, either by overruling White or by excluding judicial elections from Citizens United's holding. 
V. Appendix

Table 1: States That Regulate Campaign Speech Through Pledges or Promises and Commit Clauses

\begin{tabular}{|c|c|c|}
\hline State & $\begin{array}{c}\text { Pledges or Promises } \\
\text { Clause }\end{array}$ & Commit Clause \\
\hline Alabama & $\begin{array}{l}\text { A judicial candidate "[s]hall } \\
\text { not make any promise of } \\
\text { conduct in office other than } \\
\text { the faithful and impartial } \\
\text { performance of the duties of } \\
\text { the office." ALA. CANONS } \\
\text { OF JUDICIAL ETHICS Canon } \\
\text { 7(B)(1)(c). }\end{array}$ & \\
\hline Alaska & $\begin{array}{l}\text { A judicial candidate shall not } \\
\text { "make pledges or promises } \\
\text { of conduct in judicial office } \\
\text { other than to faithfully and } \\
\text { impartially perform the } \\
\text { duties of the office." } \\
\text { ALASKA CODE OF JUDICIAL } \\
\text { CONDUCT Canon } \\
5(A)(3)(d)(i) .\end{array}$ & $\begin{array}{l}\text { A judicial candidate shall not } \\
\text { "make statements that } \\
\text { commit or appear to commit } \\
\text { the candidate to a particular } \\
\text { view or decision with respect } \\
\text { to cases, controversies or } \\
\text { issues that are likely to come } \\
\text { before the court." ALASKA } \\
\text { CODE OF JUDICIAL CONDUCT } \\
\text { Canon 5(A)(3)(d)(ii). }\end{array}$ \\
\hline Arizona & $\begin{array}{l}\text { A judicial candidate shall not } \\
\text { "in connection with cases, } \\
\text { controversies, or issues that } \\
\text { are likely to come before the } \\
\text { court, make pledges, } \\
\text { promises, or commitments } \\
\text { that are inconsistent with the } \\
\text { impartial performance of the } \\
\text { adjudicative duties of } \\
\text { judicial office." ARIz. SuP. } \\
\text { CT. R. 81, Canon 4, R. } \\
\text { 4.1(A)(10). }\end{array}$ & \\
\hline
\end{tabular}




\begin{tabular}{|c|c|c|}
\hline State & $\begin{array}{c}\text { Pledges or Promises } \\
\text { Clause }\end{array}$ & Commit Clause \\
\hline Arkansas & $\begin{array}{l}\text { A judicial candidate shall not } \\
\text { "in connection with cases, } \\
\text { controversies, or issues that } \\
\text { are likely to come before the } \\
\text { court, make pledges, } \\
\text { promises, or commitments } \\
\text { that are inconsistent with the } \\
\text { impartial performance of the } \\
\text { adjudicative duties of } \\
\text { judicial office." ARK. CODE } \\
\text { OF JUDICIAL CONDUCT } \\
\text { Canon 4, R. 4.1(A)(13). }\end{array}$ & \\
\hline California & & $\begin{array}{l}\text { A judicial candidate shall not } \\
\text { "make statements to the } \\
\text { electorate ... that commit } \\
\text { the candidate with respect to } \\
\text { cases, controversies, or } \\
\text { issues that could come } \\
\text { before the courts." CAL. } \\
\text { CODE OF JUDICIAL ETHICS } \\
\text { Canon 5(B)(1). }\end{array}$ \\
\hline Colorado & $\begin{array}{l}\text { A judicial candidate shall not } \\
\text { "in connection with cases, } \\
\text { controversies, or issues that } \\
\text { are likely to come before the } \\
\text { court, make pledges, } \\
\text { promises, or commitments } \\
\text { that are inconsistent with the } \\
\text { impartial performance of the } \\
\text { adjudicative duties of } \\
\text { judicial office." COLO. } \\
\text { CODE OF JUDICIAL CONDUCT } \\
\text { Canon 4, R. 4.1(A)(13). }\end{array}$ & \\
\hline
\end{tabular}




\begin{tabular}{|c|c|c|}
\hline State & $\begin{array}{c}\text { Pledges or Promises } \\
\text { Clause } \\
\end{array}$ & Commit Clause \\
\hline Florida & $\begin{array}{l}\text { A judicial candidate shall not } \\
\text { "with respect to parties or } \\
\text { classes of parties, cases, } \\
\text { controversies, or issues that } \\
\text { are likely to come before the } \\
\text { court, make pledges, } \\
\text { promises, or commitments } \\
\text { that are inconsistent with the } \\
\text { impartial performance of the } \\
\text { adjudicative duties of the } \\
\text { office." FLA. CODE OF } \\
\text { JUDICIAL CONDUCT Canon } \\
\text { 7(A)(3)(e)(i). }\end{array}$ & \\
\hline Georgia & & $\begin{array}{l}\text { A judicial candidate "shall } \\
\text { not make statements that } \\
\text { commit the candidate with } \\
\text { respect to issues likely to } \\
\text { come before the court." GA. } \\
\text { CODE OF JUDICIAL CONDUCT } \\
\text { Canon 7(B)(1)(b). }\end{array}$ \\
\hline Hawaii & $\begin{array}{l}\text { A judicial candidate shall not } \\
\text { "in connection with cases, } \\
\text { controversies, or issues that } \\
\text { are likely to come before the } \\
\text { court, make pledges, } \\
\text { promises, or commitments } \\
\text { that are inconsistent with the } \\
\text { impartial performance of the } \\
\text { adjudicative duties of } \\
\text { judicial office.” HAW. REV. } \\
\text { CODE OF JUDICIAL CONDUCT } \\
\text { Canon 4, R. 4.1(a)(13). }\end{array}$ & \\
\hline Idaho & $\begin{array}{l}\text { A judicial candidate shall not } \\
\text { "make pledges or promises } \\
\text { of conduct in office other } \\
\text { than the faithful and } \\
\text { impartial performance of the } \\
\text { duties of the office." IDAHO } \\
\text { CODE OF JUDICIAL CONDUCT } \\
\text { Canon 5(A)(4)(d)(i). }\end{array}$ & $\begin{array}{l}\text { A judicial candidate shall not } \\
\text { "make statements that } \\
\text { commit or appear to commit } \\
\text { the candidate with respect to } \\
\text { cases, controversies or issues } \\
\text { that are likely to come before } \\
\text { the court." IDAHO CODE OF } \\
\text { JUDICIAL CONDUCT Canon } \\
\text { 5(A)(4)(d)(ii). }\end{array}$ \\
\hline
\end{tabular}




\begin{tabular}{|c|c|c|}
\hline State & $\begin{array}{c}\text { Pledges or Promises } \\
\text { Clause }\end{array}$ & Commit Clause \\
\hline Illinois & & $\begin{array}{l}\text { A judicial candidate shall not } \\
\text { "make statements that } \\
\text { commit or appear to commit } \\
\text { the candidate with respect to } \\
\text { cases, controversies or issues } \\
\text { within cases that are likely to } \\
\text { come before the court." ILL. } \\
\text { SuP. CT. R. 67, Canon } \\
7(\text { A)(3)(d)(i). }\end{array}$ \\
\hline Indiana & $\begin{array}{l}\text { A judicial candidate shall not } \\
\text { "in connection with cases, } \\
\text { controversies, or issues that } \\
\text { are likely to come before the } \\
\text { court, make pledges, } \\
\text { promises, or commitments } \\
\text { that are inconsistent with the } \\
\text { impartial performance of the } \\
\text { adjudicative duties of } \\
\text { judicial office." IND. CODE } \\
\text { OF JUDICIAL CONDUCT } \\
\text { Canon 4, R. 4.1(A)(13). }\end{array}$ & \\
\hline Iowa & $\begin{array}{l}\text { A judicial candidate shall not } \\
\text { "in connection with cases, } \\
\text { controversies, or issues that } \\
\text { are likely to come before the } \\
\text { court, make pledges, } \\
\text { promises, or commitments } \\
\text { that are inconsistent with the } \\
\text { impartial performance of the } \\
\text { adjudicative duties of } \\
\text { judicial office." IOWA CODE } \\
\text { OF JUDICIAL CONDUCT R. } \\
51: 4.1 \text { (A)(13). }\end{array}$ & \\
\hline
\end{tabular}




\begin{tabular}{|c|c|c|}
\hline State & $\begin{array}{c}\text { Pledges or Promises } \\
\text { Clause }\end{array}$ & Commit Clause \\
\hline Kansas & $\begin{array}{l}\text { A judicial candidate shall not } \\
\text { "in connection with cases, } \\
\text { controversies, or issues that } \\
\text { are likely to come before the } \\
\text { court, make pledges, } \\
\text { promises, or commitments } \\
\text { that are inconsistent with the } \\
\text { impartial performance of the } \\
\text { adjudicative duties of } \\
\text { judicial office.” KAN. SuP. } \\
\text { CT. R. 601B, Canon 4, R. } \\
\text { 4.1(A)(6). }\end{array}$ & \\
\hline Louisiana & $\begin{array}{l}\text { A judicial candidate shall not } \\
\text { "with respect to cases, } \\
\text { controversies, or issues that } \\
\text { are likely to come before the } \\
\text { court, make pledges, } \\
\text { promises or commitments } \\
\text { that are inconsistent with the } \\
\text { impartial performance of the } \\
\text { adjudicative duties of the } \\
\text { office.” LA. CODE OF } \\
\text { JUDICIAL CONDUCT Canon } \\
\text { 7(B)(1)(d)(i). }\end{array}$ & \\
\hline Maine & $\begin{array}{l}\text { A judicial candidate shall not } \\
\text { "make pledges or promises } \\
\text { of conduct in office other } \\
\text { than the faithful and } \\
\text { impartial performance of the } \\
\text { duties of the office." ME. } \\
\text { CODE OF JUDICIAL CONDUCT } \\
\text { Canon 5(B)(2)(a). }\end{array}$ & $\begin{array}{l}\text { A judicial candidate shall not } \\
\text { "make statements that } \\
\text { commit or appear to commit } \\
\text { the candidate with respect to } \\
\text { cases, controversies, or } \\
\text { issues that are likely to come } \\
\text { before the court." ME. CODE } \\
\text { OF JUDICIAL CONDUCT } \\
\text { Canon 5(B)(2)(b). }\end{array}$ \\
\hline
\end{tabular}




\begin{tabular}{|c|c|c|}
\hline State & $\begin{array}{c}\text { Pledges or Promises } \\
\text { Clause }\end{array}$ & Commit Clause \\
\hline Maryland & $\begin{array}{l}\text { A judicial candidate "with } \\
\text { respect to a case, } \\
\text { controversy, or issue that is } \\
\text { likely to come before the } \\
\text { court, shall not make a } \\
\text { commitment, pledge, or } \\
\text { promise that is inconsistent } \\
\text { with the impartial } \\
\text { performance of the } \\
\text { adjudicative duties of the } \\
\text { office.” MD. RULES R. 16- } \\
\text { 813, § 4, R. 4.4(d)(3). }\end{array}$ & \\
\hline Michigan & $\begin{array}{l}\text { A judicial candidate "should } \\
\text { not make pledges or } \\
\text { promises of conduct in office } \\
\text { other than the faithful and } \\
\text { impartial performance of the } \\
\text { duties of the office." MicH. } \\
\text { CODE OF JUDICIAL CONDUCT } \\
\text { Canon 7(B)(1)(c). }\end{array}$ & \\
\hline Minnesota & $\begin{array}{l}\text { A judicial candidate shall not } \\
\text { "in connection with cases, } \\
\text { controversies, or issues that } \\
\text { are likely to come before the } \\
\text { court, make pledges, } \\
\text { promises, or commitments } \\
\text { that are inconsistent with the } \\
\text { impartial performance of the } \\
\text { adjudicative duties of } \\
\text { judicial office.” MinN. } \\
\text { CODE OF JUDICIAL CONDUCT } \\
\text { Canon 4, R. 4.1(A)(11). }\end{array}$ & \\
\hline Mississippi & $\begin{array}{l}\text { A judicial candidate shall not } \\
\text { "make pledges or promises } \\
\text { of conduct in office other } \\
\text { than the faithful and } \\
\text { impartial performance of the } \\
\text { duties of the office." Miss. } \\
\text { CODE OF JUDICIAL CONDUCT } \\
\text { Canon 5(A)(3)(d)(i). }\end{array}$ & $\begin{array}{l}\text { A judicial candidate shall not } \\
\text { "make statements that } \\
\text { commit or appear to commit } \\
\text { the candidate with respect to } \\
\text { cases, controversies or issues } \\
\text { that are likely to come before } \\
\text { the court." Miss. CODE OF } \\
\text { JUDICIAL CONDUCT Canon } \\
\text { 5(A)(3)(d)(ii). }\end{array}$ \\
\hline
\end{tabular}




\begin{tabular}{|c|c|c|}
\hline State & $\begin{array}{c}\text { Pledges or Promises } \\
\text { Clause }\end{array}$ & Commit Clause \\
\hline Missouri & $\begin{array}{l}\text { A judicial candidate "shall } \\
\text { not make pledges or } \\
\text { promises of conduct in office } \\
\text { other than the faithful and } \\
\text { impartial performance of the } \\
\text { duties of the office." Mo. } \\
\text { SuP. CT. R. 2.03, Canon } \\
\text { 5(B)(1)(c). }\end{array}$ & \\
\hline Montana & $\begin{array}{l}\text { A judicial candidate shall not } \\
\text { "in connection with cases, } \\
\text { controversies, or issues that } \\
\text { are likely to come before the } \\
\text { court, make pledges, } \\
\text { promises, or commitments } \\
\text { that are inconsistent with the } \\
\text { impartial performance of the } \\
\text { adjudicative duties of } \\
\text { judicial office." MONT. } \\
\text { CODE OF JUDICIAL CONDUCT } \\
\text { Canon 4, R. 4.1(A)(12). }\end{array}$ & \\
\hline Nebraska & $\begin{array}{l}\text { A judicial candidate shall not } \\
\text { "make pledges or promises } \\
\text { of conduct in office other } \\
\text { than the faithful and } \\
\text { impartial performance of the } \\
\text { duties of the office." NEB. } \\
\text { CODE OF JUDICIAL CONDUCT } \\
\text { § 5-205, Canon } \\
5(A)(3)(d)(i) .\end{array}$ & $\begin{array}{l}\text { A judicial candidate shall not } \\
\text { "make statements that } \\
\text { commit or appear to commit } \\
\text { the candidate with respect to } \\
\text { cases, controversies, or } \\
\text { issues that are likely to come } \\
\text { before the court." NEB. } \\
\text { CODE OF JUDICIAL CONDUCT } \\
\text { § 5-205, Canon } \\
5(\mathrm{~A})(3)(\mathrm{d})(\mathrm{ii}) .\end{array}$ \\
\hline Nevada & $\begin{array}{l}\text { A judicial candidate shall not } \\
\text { "with respect to cases, } \\
\text { controversies, or issues that } \\
\text { are likely to come before the } \\
\text { court, make pledges, } \\
\text { promises or commitments } \\
\text { that are inconsistent with the } \\
\text { impartial performance of the } \\
\text { adjudicative duties of the } \\
\text { office." NEV. CODE OF } \\
\text { JuDICIAL CONDUCT Canon 4, } \\
\text { R. 4.1(A)(13). }\end{array}$ & \\
\hline
\end{tabular}




\begin{tabular}{|c|c|c|}
\hline State & $\begin{array}{c}\text { Pledges or Promises } \\
\text { Clause }\end{array}$ & Commit Clause \\
\hline $\begin{array}{c}\text { New } \\
\text { Hampshire }\end{array}$ & $\begin{array}{l}\text { A judicial candidate shall not } \\
\text { "with respect to cases, } \\
\text { controversies, or issues that } \\
\text { are likely to come before the } \\
\text { court, make pledges, } \\
\text { promises or commitments } \\
\text { that are inconsistent with the } \\
\text { impartial performance of the } \\
\text { adjudicative duties of the } \\
\text { office." N.H. Sup. CT. R. 38, } \\
\text { Canon 5(B)(1)(b)(i). }\end{array}$ & \\
\hline New Mexico & $\begin{array}{l}\text { A judicial candidate shall not } \\
\text { "with respect to cases, } \\
\text { controversies or issues that } \\
\text { are likely to come before the } \\
\text { court, make pledges, } \\
\text { promises or commitments } \\
\text { that are inconsistent with the } \\
\text { impartial performance of the } \\
\text { adjudicative duties of the } \\
\text { office.” N.M. SuP. Cт. R. } \\
\text { 21-700(B)(4)(a). }\end{array}$ & \\
\hline New York & $\begin{array}{l}\text { A judicial candidate shall not } \\
\text { "make pledges or promises } \\
\text { of conduct in office that are } \\
\text { inconsistent with the } \\
\text { impartial performance of the } \\
\text { adjudicative duties of the } \\
\text { office." N.Y. CT. R. } \\
\S 100.5(A)(4)(d)(i) .\end{array}$ & $\begin{array}{l}\text { A judicial candidate shall not } \\
\text { "with respect to cases, } \\
\text { controversies or issues that } \\
\text { are likely to come before the } \\
\text { court, make commitments } \\
\text { that are inconsistent with the } \\
\text { impartial performance of the } \\
\text { adjudicative duties of the } \\
\text { office." N.Y. CT. R. } \\
\S 100.5(A)(4)(d)(\text { ii). }\end{array}$ \\
\hline
\end{tabular}




\begin{tabular}{|c|c|c|}
\hline State & $\begin{array}{c}\text { Pledges or Promises } \\
\text { Clause }\end{array}$ & Commit Clause \\
\hline $\begin{array}{l}\text { North } \\
\text { Dakota }\end{array}$ & $\begin{array}{l}\text { A judicial candidate shall not } \\
\text { "with respect to cases, } \\
\text { controversies, or issues that } \\
\text { are likely to come before the } \\
\text { court, make pledges, } \\
\text { promises or commitments } \\
\text { that are inconsistent with the } \\
\text { impartial performance of the } \\
\text { adjudicative duties of the } \\
\text { office.” N.D. CODE OF } \\
\text { JUDICIAL CONDUCT Canon } \\
\text { 5(A)(3)(d)(i). }\end{array}$ & \\
\hline Ohio & $\begin{array}{l}\text { A judicial candidate shall not } \\
\text { "[i]n connection with cases, } \\
\text { controversies, or issues that } \\
\text { are likely to come before the } \\
\text { court, make pledges, } \\
\text { promises, or commitments } \\
\text { that are inconsistent with the } \\
\text { impartial performance of the } \\
\text { adjudicative duties of } \\
\text { judicial office.” OHIO CODE } \\
\text { OF JUDICIAL CONDUCT } \\
\text { Canon 4, R. 4.1(A)(7). }\end{array}$ & \\
\hline Oklahoma & $\begin{array}{l}\text { A judicial candidate shall } \\
\text { not, "in connection with } \\
\text { cases, controversies, or } \\
\text { issues that are likely to come } \\
\text { before the court, make } \\
\text { pledges, promises, or } \\
\text { commitments that are } \\
\text { inconsistent with the } \\
\text { impartial performance of the } \\
\text { adjudicative duties of } \\
\text { judicial office.” OKLA. } \\
\text { CODE OF JUDICIAL CONDUCT } \\
\text { Canon 4, R. 4.1(A)(13). }\end{array}$ & \\
\hline
\end{tabular}




\begin{tabular}{|c|c|c|}
\hline State & $\begin{array}{c}\text { Pledges or Promises } \\
\text { Clause }\end{array}$ & Commit Clause \\
\hline Oregon & $\begin{array}{l}\text { A judicial candidate shall not } \\
\text { "[m]ake pledges or promises } \\
\text { of conduct in office that } \\
\text { could inhibit or compromise } \\
\text { the faithful, impartial and } \\
\text { diligent performance of the } \\
\text { duties of the office." OR. } \\
\text { CODE OF JUDICIAL CONDUCT } \\
\text { JUD. R. 4-102(B). }\end{array}$ & \\
\hline Pennsylvania & $\begin{array}{l}\text { A judicial candidate "should } \\
\text { not make pledges or } \\
\text { promises of conduct in office } \\
\text { other than the faithful and } \\
\text { impartial performance of the } \\
\text { duties of the office." PA. } \\
\text { CODE OF JUDICIAL CONDUCT } \\
\text { Canon 7(B)(1)(c). }\end{array}$ & $\begin{array}{l}\text { A judicial candidate should } \\
\text { not "make statements that } \\
\text { commit the candidate with } \\
\text { respect to cases, } \\
\text { controversies or issues that } \\
\text { are likely to come before the } \\
\text { court.” PA. CODE OF } \\
\text { JUDICIAL CONDUCT Canon } \\
\text { 7(B)(1)(c). }\end{array}$ \\
\hline $\begin{array}{l}\text { Rhode } \\
\text { Island }\end{array}$ & $\begin{array}{l}\text { A judicial candidate shall not } \\
\text { "make pledges or promises } \\
\text { of conduct in office other } \\
\text { than the faithful and } \\
\text { impartial performance of the } \\
\text { duties of the office." R.I. } \\
\text { CODE OF JUDICIAL CONDUCT } \\
\text { Canon 5(A)(3)(d)(i). }\end{array}$ & $\begin{array}{l}\text { A judicial candidate shall not } \\
\text { "make statements that } \\
\text { commit or appear to commit } \\
\text { the candidate with respect to } \\
\text { cases, controversies or issues } \\
\text { that are likely to come before } \\
\text { the court." R.I. CODE OF } \\
\text { JUDICIAL CONDUCT Canon } \\
\text { 5(A)(3)(d)(ii). }\end{array}$ \\
\hline $\begin{array}{c}\text { South } \\
\text { Carolina }\end{array}$ & $\begin{array}{l}\text { A judicial candidate shall not } \\
\text { "make pledges or promises } \\
\text { of conduct in office other } \\
\text { than the faithful and } \\
\text { impartial performance of the } \\
\text { duties of the office." S.C. } \\
\text { ApP. CT. R. 501, Canon } \\
\text { 5(A)(3)(d)(i). }\end{array}$ & $\begin{array}{l}\text { A judicial candidate shall not } \\
\text { "make statements that } \\
\text { commit or appear to commit } \\
\text { the candidate with respect to } \\
\text { cases, controversies or issues } \\
\text { that are likely to come before } \\
\text { the court." S.C. App. CT. R. } \\
\text { 501, Canon 5(A)(3)(d)(ii). }\end{array}$ \\
\hline
\end{tabular}




\begin{tabular}{|c|c|c|}
\hline State & $\begin{array}{c}\text { Pledges or Promises } \\
\text { Clause } \\
\end{array}$ & Commit Clause \\
\hline $\begin{array}{l}\text { South } \\
\text { Dakota }\end{array}$ & $\begin{array}{l}\text { A judicial candidate shall not } \\
\text { "with respect to cases, } \\
\text { controversies, or issues that } \\
\text { are likely to come before the } \\
\text { court, make pledges, } \\
\text { promises or commitments } \\
\text { that are inconsistent with the } \\
\text { impartial performance of the } \\
\text { adjudicative duties of the } \\
\text { office." S.D. CODE OF } \\
\text { JuDICIAL CONDUCT Canon } \\
\text { 5(A)(3)(d)(i). }\end{array}$ & \\
\hline Tennessee & $\begin{array}{l}\text { A judicial candidate shall not } \\
\text { "make pledges or promises } \\
\text { of conduct in office other } \\
\text { than the faithful and } \\
\text { impartial performance of the } \\
\text { duties of the office." TENN. } \\
\text { SuP. CT. R. 10, Canon } \\
\text { 5(A)(3)(d)(i). }\end{array}$ & $\begin{array}{l}\text { A judicial candidate shall not } \\
\text { "make statements that } \\
\text { commit or appear to commit } \\
\text { the candidate with respect to } \\
\text { cases, controversies, or } \\
\text { issues that are likely to come } \\
\text { before the court." TENN. } \\
\text { SuP. CT. R. 10, Canon } \\
\text { 5(A)(3)(d)(ii). }\end{array}$ \\
\hline Texas & $\begin{array}{l}\text { A judicial candidate shall not } \\
\text { "make pledges or promises } \\
\text { of conduct in office } \\
\text { regarding pending or } \\
\text { impending cases, specific } \\
\text { classes of cases, specific } \\
\text { classes of litigants, or } \\
\text { specific propositions of law } \\
\text { that would suggest to a } \\
\text { reasonable person that the } \\
\text { judge is predisposed to a } \\
\text { probable decision in cases } \\
\text { within the scope of the } \\
\text { pledge." TEX. CODE OF } \\
\text { JUDICIAL CONDUCT Canon } \\
\text { 5(1)(i). }\end{array}$ & \\
\hline
\end{tabular}




\begin{tabular}{|c|c|c|}
\hline State & $\begin{array}{c}\text { Pledges or Promises } \\
\text { Clause }\end{array}$ & Commit Clause \\
\hline Utah & $\begin{array}{l}\text { A judicial candidate shall not } \\
\text { "make pledges, promises, or } \\
\text { commitments other than the } \\
\text { faithful, impartial and } \\
\text { diligent performance of } \\
\text { judicial duties." UTAH CODE } \\
\text { OF JUDICIAL CONDUCT } \\
\text { Canon 4, R. 4.1(A)(11). }\end{array}$ & \\
\hline Vermont & $\begin{array}{l}\text { A judicial candidate shall not } \\
\text { "make pledges or promises } \\
\text { of judicial conduct other } \\
\text { than the faithful and } \\
\text { impartial performance of the } \\
\text { duties of the office." VT. } \\
\text { CODE OF JUDICIAL CONDUCT } \\
\text { Canon 5(B)(4)(a). }\end{array}$ & $\begin{array}{l}\text { A judicial candidate shall not } \\
\text { "make statements that } \\
\text { commit or appear to commit } \\
\text { the candidate with respect to } \\
\text { cases, controversies, or } \\
\text { issues that are likely to come } \\
\text { before the court." VT. CODE } \\
\text { OF JUDICIAL CoNDUCT } \\
\text { Canon 5(B)(4)(b). }\end{array}$ \\
\hline Washington & $\begin{array}{l}\text { A judicial candidate shall } \\
\text { not, "in connection with } \\
\text { cases, controversies, or } \\
\text { issues that are likely to come } \\
\text { before the court, make } \\
\text { pledges, promises, or } \\
\text { commitments that are } \\
\text { inconsistent with the } \\
\text { impartial performance of the } \\
\text { adjudicative duties of } \\
\text { judicial office." WASH. } \\
\text { CODE OF JUDICIAL CONDUCT } \\
\text { Canon 4, R. 4.1(A)(12). }\end{array}$ & \\
\hline $\begin{array}{c}\text { West } \\
\text { Virginia }\end{array}$ & $\begin{array}{l}\text { A judicial candidate shall not } \\
\text { "make pledges or promises } \\
\text { of conduct in office other } \\
\text { than the faithful and } \\
\text { impartial performance of the } \\
\text { duties of the office." W. VA. } \\
\text { CODE OF JUDICIAL CONDUCT } \\
\text { Canon 5(A)(3)(d)(i). }\end{array}$ & $\begin{array}{l}\text { A judicial candidate shall not } \\
\text { "make statements that } \\
\text { commit or appear to commit } \\
\text { the candidate with respect to } \\
\text { cases, controversies or issues } \\
\text { that are likely to come before } \\
\text { the court." W. VA. CODE OF } \\
\text { JUDICIAL CONDUCT Canon } \\
\text { 5(A)(3)(d)(ii). }\end{array}$ \\
\hline
\end{tabular}




\begin{tabular}{|c|c|c|}
\hline State & $\begin{array}{c}\text { Pledges or Promises } \\
\text { Clause }\end{array}$ & Commit Clause \\
\hline Wisconsin & $\begin{array}{l}\text { A judicial candidate shall not } \\
\text { "make ... with respect to } \\
\text { cases, controversies, or } \\
\text { issues that are likely to come } \\
\text { before the court, pledges, } \\
\text { promises, or commitments } \\
\text { that are inconsistent with the } \\
\text { impartial performance of the } \\
\text { adjudicative duties of the } \\
\text { office.” Wis. SUP. CT. R. } \\
60.06(3)(\text { b). }\end{array}$ & \\
\hline Wyoming & $\begin{array}{l}\text { A judicial candidate shall } \\
\text { "not make pledges or } \\
\text { promises of conduct in office } \\
\text { other than the faithful and } \\
\text { impartial performance of the } \\
\text { duties of the office; [nor] } \\
\text { announce how the judge } \\
\text { would rule on any case or } \\
\text { issue that might come before } \\
\text { the judge." WYO. CODE OF } \\
\text { JuDICIAL CONDUCT Canon 4, } \\
\text { R. 4.2(A)(5). }\end{array}$ & \\
\hline
\end{tabular}

